Please cite as:

Martinez-Hernandez, Elias; Martinez-Herrera, Jorge; Campbell, Grant M.; Sadhukhan, Jhuma. Process integration, energy and GHG emission analyses of Jatropha-based biorefinery systems. Biomass Conversion and Biorefinery 2014; 4(2):105-124.

\title{
Process integration, energy and GHG emission analyses of Jatropha-based biorefinery
} systems

Elias Martinez-Hernandez ${ }^{1}$, Jorge Martinez-Herrera ${ }^{2}$, Grant M. Campbell ${ }^{1}$ and Jhuma Sadhukhan ${ }^{3 *}$ ${ }^{1}$ Centre for Process Integration, School of Chemical Engineering and Analytical Science, University of Manchester, Manchester, M13 9PL, UK.

${ }^{2}$ ENERGY J.H. S.A. de C.V., Texcoco, Estado de Mexico, ZIP 56130, Mexico. ${ }^{3}$ Centre for Environmental Strategy, University of Surrey, Guildford, GU2 7XH, UK.

\section{ABSTRACT}

Driven by the need to develop a wide variety of products with low environmental impact, biorefineries need to emerge as highly integrated facilities. This becomes effective when overall mass and energy integration through a centralised utility system design is undertaken. An approach combining process integration, energy and greenhouse gas (GHG) emission analyses is shown in this paper for Jatropha biorefinery design, primarily producing biodiesel using oil-based heterogeneously catalysed transesterification or green diesel using hydrotreatment. These processes are coupled with gasification of husk to produce syngas. Syngas is converted into end products, heat, power and methanol in the biodiesel case or hydrogen in the green diesel case. Anaerobic digestion of Jatropha by-products such as fruit shell, cake and/or glycerol has been considered to produce biogas for power generation. Combustion of fruit shell and cake is considered to provide heat. Heat recovery within biodiesel or green diesel production and the design of the utility (heat and power) system are also shown. The biorefinery systems wherein cake supplies heat for oil extraction and seed drying while fruit shells and glycerol provide power generation via anaerobic digestion into biogas, achieve energy efficiency of 53\% in the biodiesel system and $57 \%$ in the 
green diesel system. These values are based on high heating values (HHV) of Jatropha feedstocks, HHV of the corresponding products and excess power generated. Results showed that both systems exhibit an energy yield per unit of land of $83 \mathrm{GJ} \mathrm{ha}^{-1}$. The global warming potential from GHG emissions of the net energy produced (i.e. after covering energy requirements by the biorefinery systems) was $29 \mathrm{~g} \mathrm{CO}_{2}$-eq $\mathrm{MJ}^{-1}$, before accounting credits from displacement of fossil-based energy by bioenergy exported from the biorefineries. Using a systematic integration approach for utilisation of whole Jatropha fruit, it is shown that global warming potential and fossil primary energy use can be reduced significantly if the integrated process schemes combined with optimised cultivation and process parameters are adopted in Jatropha-based biorefineries.

Keywords: biodiesel, green diesel, biorefinery, utility system design, LCA, process integration.

\footnotetext{
* Author/s to whom correspondence should be addressed:
}

E-mail: jhumasadhukhan@gmail.com, Ph: +44 148368 6642, Fax: +44 1483686671.

\section{Introduction}

Jatropha curcas as feedstock for the production of biofuels has been explored in recent years in tropical countries (such as India, China, Malaysia, Indonesia, Mozambique, Brazil, Mexico, etc.) with about $12000 \mathrm{~km}^{2}$ of plantations globally in 2011 [1]. In order to establish Jatropha curcas as a competitive energy crop, the whole fruit must be exploited by extraction of valuable components and conversion into added value products [2],[3]. This can be achieved in integrated biorefineries as shown for other feedstocks such as wheat [4]. Major Jatropha fruit fractions include fruit shells, seed husks, oil and cake after oil extraction from the kernel, presented along with compositions and energy values in Table 1. Jatropha oil has been extensively investigated for biodiesel production (with glycerol co-production) using homogeneous and heterogeneous catalysis [5], [6]. Heterogeneous catalysts (e.g. $\mathrm{MgO}, \mathrm{CaO}$, zeolites) facilitate separation of products and provide greater flexibility to free fatty acid content in oil [6]. An alternative to biodiesel is green diesel, which is produced by hydrotreatment of vegetable oils. Propane fuel is also generated as coproduct from this process [7]. This process has the advantage of the biofuel products being readily 
adaptable to current infrastructure. Throughout the paper, the term biodiesel is used to indicate the diesel produced by transesterification. Green diesel is the diesel produced by hydrotreatment.

\section{Table 1}

Conversion of the whole Jatropha fruit (not only the oil) into energy products (biofuel, heat, power) has more energy output than only biofuel production from the oil [8]. The suitability of extraction cake as an added value product has been studied [9]-[14]. It has been shown that cake from toxic Jatropha genotypes needs detoxification prior to its use as a valuable source of protein and potential substitute for soy meal in animal feed [11], [13]. However, non-toxic genotypes as those native to Mexico make the extraction cake suitable for animal feed [9], [10]. An alternative use of Jatropha cake is as an organic fertiliser [12], [14], [15]. Cake and fruit shells are a good substrate for anaerobic digestion into biogas [16]-[18]. The glycerol generated as co-product in the biodiesel production process has also been studied as a potential feedstock for biogas generation [19], [20]. Jatropha seed husk has been explored as an attractive feedstock for gasification and pyrolysis [8], [21], [22]. These thermochemical processes can produce syngas for the generation of liquid fuels, chemicals, heat and power from residues [23]-[29]. This opens process integration opportunities in the biorefinery to produce required raw materials such as methanol (used in the transesterification of Jatropha oil to produce biodiesel) or hydrogen (used in the hydrotreatment of vegetable oil to produce green diesel) internally. With systematic selection and process integration of co-production routes, fossil energy use and global warming impact of biorefineries can be reduced [25]-[29].

Life cycle assessment (LCA) is an effective tool for analysing material and energy inventories and environmental impacts throughout a product or process life cycle [30]-[35]. LCA studies of Jatropha-based bioenergy systems showed that reductions in greenhouse gas (GHG) emissions in the range of 55\%-90\% with savings in cumulative fossil primary energy (CPE) of more than $70 \%$, in respect to a reference fossil-based system are achievable by converting the various Jatropha fruit fractions [5], [32]-[35]. Although these studies considered utilisation of various Jatropha fruit 
78 fractions and various conversion routes, potential benefits from process integration opportunities

79 have not been explored.

80 Starting with an effort to improve energy efficiency of process industries in 1970s, the process

81 integration tools [36]-[41] have been widely applied with valuable contributions in the field of 82 biorefineries such as process synthesis [39], [40], heat and mass integration [23]-[25], pollution and 83 GHG emission control [41], optimisation of process and supply chain [42], and of energy and 84 material efficiency for reduced energy consumption [43]. This work proposes an effective 85 framework combining process integration tools and LCA approach for more resource efficient 86 biorefinery design. It is a matter of urgency to investigate systematic process integration synergies 87 and compare the energy and global warming impact from greenhouse gas (GHG) emissions 88 between biorefinery integration alternatives. This paper shows comparison of GHG emissions and 89 energetic efficiencies between green diesel and biodiesel productions from integrated Jatropha 90 biorefinery systems in which the required electrical and thermal energy and hydrogen or methanol 91 are generated from Jatropha residues.

2. Methodology

\subsection{Goal and system definition}

94 The objective of this work is to produce integrated biorefinery schemes from Jatropha fruit for the 95 production of biofuels, power and co-products and assess their GHG emissions and cumulative primary energy (CPE) using life cycle analysis. The energy efficiency is also assessed. The assessment is to show the need and advantages that can be obtained from optimisation of system parameters (such as yields and energy efficiencies), process integration and the use of advanced technologies for future deployment.

Fig. 1 presents an overview of the systems considered in this study. Two alternative biofuel production systems are studied: biodiesel and green diesel. The base case comprises the standalone biofuel plants wherein the oil is the only Jatropha fruit fraction, converted into either biodiesel and 
$\mathrm{CO}_{2}$ ), with the oil extraction cake as a by-product in both cases. In these stand-alone systems, any utility requirements, after internal process integration, are supplied from fossil sources.

In the 'integrated biodiesel or green diesel systems', the husk is gasified into syngas which is used to supply heat and power, along with either methanol for biodiesel or hydrogen for green diesel productions. Any excess heat is converted into power via steam generation. The excess power is then exported to the electricity grid. In the base case and the integrated systems, the glycerol and propane are exported as fuels and the cake as animal feed. As shown in Fig. 1, five alternatives for the use of fruit shells, extraction cake and glycerol within the integrated systems are proposed for the whole Jatropha utilisation to improve conversion efficiency:

1) Cake is burned to supply heat for oil extraction (wherein natural gas is substituted) and seed drying (wherein diesel is substituted).

2) Fruit shells are used as fuel to provide heat for oil extraction and seed drying. Cake is used as fertiliser replacing part of the inorganic fertilisers currently used.

3) The same as alternative 2, but cake is sold as animal feed. Soy meal is replaced by the cake.

4) Cake, fruit shells and glycerol in the biodiesel case, are used in anaerobic digestion. The biogas produced is converted into electricity.

5) Cake supplying heat for oil extraction and seed drying as in alternative 1. The fruit shells and glycerol in the biodiesel system are used as in alternative 4.

Fig. 1 Overview of the integrated Jatropha biorefinery systems for the production of biodiesel and green diesel with utilities and auxiliary raw materials generated from Jatropha by-products. Numbers 1-5 indicate in which alternative the options for by-product utilisation are selected. Mass flow rate in $\mathrm{Gg}^{-1}$, heat and electricity in $\mathrm{PJ} \mathrm{y}^{-1}$. IBGCC: Integrated biomass gasification and combined cycle

Substitution approach by taking credits from co-products has been used. GHG emissions have been characterised by their global warming potential (GWP) impact as $\mathrm{CO}_{2}$-eq. The biorefinery is assumed to be located within the radius of plantations of the non-toxic genotype in Michoacan, Mexico. Transportation distance for fruit shells, seeds and cake is equal to the radius of the plantation land assuming a circular shape. The transportation of auxiliary raw materials and 
132

biorefinery products are assumed to be $100 \mathrm{~km}$. The cumulative primary energy (CPE) and GWP factors are based on road transportation using 100\% fossil-based diesel [45]. The embodied CPE and GWP impact of the various fuels and raw materials are extracted from various sources [45][49] and are presented in Table 2. The fossil-based cumulative primary energy and environmental impact data for power are deduced from [46] and the Mexican national electricity mix data (natural gas $=51.8 \%$, fuel oil $=16.7 \%$, coal $=12.4 \%$, diesel $=0.5 \%$, renewable $=14.1 \%$ and nuclear $=4.5 \%$ by energy) [50].

\section{Table 2}

\subsection{Modelling approaches for inventories}

The systematic analysis comprises detailed modelling for the Jatropha cultivation, including seed yield modelling, and seed drying and conditioning using spreadsheet calculations. Spreadsheet based models were also used for seed processing, anaerobic digestion and biogas conversion to power. Process simulations using Aspen Plus ${ }^{\circledR}$ were developed to estimate the inventories from the various conversion processes. The basis for the mass and energy balances is the production of 100 $\mathrm{Gg}^{-1}$ of biodiesel from 104.7 $\mathrm{Gg} \mathrm{y}^{-1}$ of Jatropha oil. The same amount of Jatropha oil produces 93.4 $\mathrm{Gg} \mathrm{y}^{-1}$ of green diesel. These amounts also set the mass and energy flow rates of all other Jatropha fractions and by-products based on the yields provided in Table 1. Final results are then shown for $1 \mathrm{MJ}$ of biofuel production for comparison. However, results are also shown in other transferrable units such as per unit of land or per unit of mass for comparisons with equivalent systems. The results from Jatropha cultivation and seed processing are common to all the alternatives studied (standalone and integrated systems). Raw material and energy inventory data are then extracted for overall system GWP and CPE assessments. The various modelling approaches required by the main subsystems in the overall Jatropha system are presented as follows.

\subsubsection{Jatropha yield model and cultivation system}


An empirical model correlating seed yield to average annual rainfall $(A A R)$ and nitrogen fertilisation rate is shown using reported seed yield from field experiences around the world presented in Table 3 .

\section{Table 3}

The annual seed yields at maturity $Y_{m a t}$ in $\mathrm{kg} \mathrm{ha}^{-1} ; 1 \mathrm{ha}=0.01 \mathrm{~km}^{2}$ ) under natural conditions, i.e. without nutrient or water management, in Table 3 were determined from the Chapman-Richards correlation shown in Eq. 1 [51]. $Y_{\text {age }}$ in $\left(\mathrm{kg} \mathrm{ha}^{-1}\right)$ is the yield at a given plant age $(A)$ and the model coefficients for Jatropha are $b=0.852$ and $c=3.466$ [51].

$$
Y_{a g e}=Y_{m a t}\left(1-e^{-b A}\right)^{c}
$$

Assuming that the yield values in Table $\mathbf{3}$ are for Jatropha grown under rain fed conditions, the calculated values of $Y_{m a t}$ are correlated to $A A R$. A third order polynomial function can applied to fit the data in Table 3 as shown in Eq. 2

$$
Y_{m a t}^{A A R}=a_{1} A A R^{3}+a_{2} A A R^{2}-a_{3} A A R
$$

$Y_{m a t}^{A A R}$ is the annual seed yield at maturity (in $\mathrm{kg} \mathrm{ha}^{-1}$ ) and a given $A A R$ (in $\mathrm{mm}$ ). The values of the polynomial constants are $a_{1}=-5.6163 \times 10^{-6}, a_{2}=1.3663 \times 10^{-2}$ and $a_{3}=5.2481$.

The annual seed yield at maturity considering nitrogen fertilisation is correlated to its base value at annual average rainfall of a location and the nitrogen fertilisation rate. The resulting function is shown in Eq. 3. This equation was developed based on conditions [53], similar to plantations located in Michoacan, Mexico.

$Y_{m a t}^{N}=Y_{m a t}^{A A R}+b_{1}\left(1-e^{-b_{2} N}\right)-b_{3} N$

$Y_{\text {mat }}^{N}\left(\right.$ in $\mathrm{kg} \mathrm{ha}^{-1}$ ) is the annual seed yield at maturity considering nitrogen fertilisation. $N$ is the nitrogen fertilisation rate $\left(\mathrm{kg} \mathrm{ha}^{-1}\right)$. The values of the constants are $b_{1}=2142, b_{2}=0.046$ and $b_{3}=1.096$.

The Jatropha field measurement from a plantation in Michoacan, Mexico was used as a test case to validate the model. A nitrogen fertilisation rate of $162 \mathrm{~kg} \mathrm{ha}^{-1}$ is applied and the $A A R$ of the location 
182

183

184

185

is $900 \mathrm{~mm}$. Doing a backward calculation from Eq. 3 to Eq. 1, the estimated seed yield in the fifth year was $Y_{\text {age }}=4010 \mathrm{~kg} \mathrm{ha}^{-1}$. The observed annual seed yield is $Y_{\text {age }}=4000 \mathrm{~kg} \mathrm{ha}^{-1}$ in the fifth year. Comparing the predicted and observed value of $Y_{\text {age }}$, the error was $0.25 \%$.

The plantation in Michoacan, Mexico used for model validation above was taken as a basis for CPE and GWP assessment of Jatropha cultivation. The different stages in a Jatropha cultivation system are shown in Fig. 2. A lifespan of 24 years was considered including four years to allow plants to reach maturity (establishment stage). The inventories in the Jatropha cultivation are summarised in Table 4. The estimated seed yield at maturity of $4213 \mathrm{~kg} \mathrm{ha}^{-1}$, from the yield model, was employed in LCA calculations. This value is well within the range of reported maximum yields. The theoretical maximum for managed cultivations under optimum conditions has been estimated as $7800 \mathrm{~kg} \mathrm{ha}^{-1}$ [15]. The maximum yields of $4500 \mathrm{~kg} \mathrm{ha}^{-1}$ in Nicaragua [54] and about $9000 \mathrm{~kg} \mathrm{ha}^{-1}$ in Thailand [55] were reported for managed cultivations.

Fig. 2 The Jatropha cultivation system producing seeds conditioned in field

\section{Table 4}

The energy yield produced in the form of seeds is $114.3 \mathrm{GJ} \mathrm{ha}^{-1}$ and in the form of fruit shells is 32.7 GJ ha ${ }^{-1}$, respectively (based on the heating values given in Table 1). The land use requirement for the production of $104.7 \mathrm{Gg} \mathrm{y}^{-1}$ of oil is about $64385 \mathrm{ha}\left(644 \mathrm{~km}^{2}\right)$. The calculated radius is 14.3 $\mathrm{km}$ for the Jatropha seed production of $271.2 \mathrm{Gg} \mathrm{y}^{-1}$ required for the extraction of $104.7 \mathrm{Gg} \mathrm{y}^{-1}$ of oil. This is the transportation distance assumed for seeds, shells and cake. Actual distances considering the non-linearity of the transportation roads can be used if known. Alternatively a sensitivity analysis is recommended. However, the contribution from transportation to the total CPE and GWP of the biofuel systems were found to be less than $1 \%$ (see Fig. 9).

\subsubsection{Seed processing}

Dried seeds transported to the biorefinery plant are first dehusked into kernel and husks. Kernels are sent to an integrated solvent oil extraction process producing high quality oil and dried cake. In the stand alone systems, the seed husks are not considered as a co-product. Inventories consist of 
electricity, heat and make-up hexane and were determined according to [56]. The values in the

209 reference were transformed from a seed mass basis to a kernel mass basis.

\section{$210 \quad$ 2.2.3 Biodiesel plant}

211 Inventories of a biodiesel plant were determined by simulating the plant in Aspen Plus in Fig. 3, 212 based on process specifications in Table 5. Oil was modelled as a mixture of tryglycerides (TG) 213 made up of four major fatty acid components (triolein, tripalmitin, trilinolein and tristearin) and free 214 fatty acids (FFA) content as oleic acid. Oil composition is shown along with the mass balance in 215 Table 9 in the Appendix. Component properties were predicted using the UNIFAC-Dortmund 216 model [57].

217 Fig. 3 Simulation of biodiesel production plant by heterogeneous transesterification of Jatropha oil Table 5

A transesterification process was considered using calcium oxide as a solid heterogeneous catalyst at $70^{\circ} \mathrm{C}$ and a methanol-to-oil molar ratio of 9 . The conversion of triglycerides is $93 \%$ and of the free fatty acids is assumed to be $100 \%$ [6]. Excess methanol was recovered by vacuum distillation and recycled. Distillation facilitated downstream separation between glycerol and methyl ester phases in a decanter. Thus, water washing and neutralisation reactors required in a typical homogeneously-catalysed process were avoided. It is assumed here that glycerol is sold as fuel. Heat integration was carried out using hot and cold composite curve analyses [36]. The reaction mix stream was preheated by the bottom stream of the methanol recovery column, before entering the transesterification reactor. The crude biodiesel stream fed to the recovery column was preheated by the distillate biodiesel stream. After heat recovery, $0.11 \mathrm{PJ} \mathrm{y}^{-1}$ of medium pressure (MP) steam and $0.04 \mathrm{PJ} \mathrm{y}^{-1}$ of high pressure (HP) steam were required.

\subsubsection{Green diesel plant}

231 Jatropha oil conversion to renewable or green diesel was simulated based on NREL (US) studies, 232 which were validated against pilot plant results [7]. Fig. 4 shows the flowsheet for the green diesel process. The same amount of oil feed $\left(104.7 \mathrm{Gg} \mathrm{y}^{-1}\right)$ as in the biodiesel plant was inputted to the 
simulation. The mass balance is shown in Table 10 in the Appendix. Hydrogen from natural gas steam reforming was supplied to the plant. The yield fractions and the complete set of specifications 236 for the simulation are summarised in Table 6. Green diesel was modelled as $\mathrm{C}_{18} \mathrm{H}_{38} .0 .027 \mathrm{~kg}$ of 237 fresh $\mathrm{H}_{2}$ and $0.028 \mathrm{~kg}$ of LP steam $(0.5 \mathrm{MPa})$ were required for the processing of $1 \mathrm{~kg}$ of Jatropha oil. 93.4 $\mathrm{Gg} \mathrm{y}^{-1}$ of green diesel was separated through flashing and stripping with low pressure (LP) steam. Thus, $1.121 \mathrm{~kg}$ of Jatropha oil is required to produce $1 \mathrm{~kg}$ of green diesel. $3.4 \mathrm{Gg} \mathrm{y}^{-1}$ of propane fuel is co-produced. The process incurred a direct $\mathrm{CO}_{2}$ emission per unit of mass of green 241 diesel equal to $0.12 \mathrm{~kg} \mathrm{~kg}^{-1}$.

242 Fig. 4 Simulation of green diesel production plant by hydrotreatment of Jatropha oil Table 6

\subsubsection{Husk gasification systems}

The proposed integrated biomass gasification and combined cycle (IBGCC) scheme converts seed husk in an allothermal gasifier into a gas rich in hydrogen and CO [24]. The gasifier comprises of a fluidised bed steam gasification reactor and a char combustor for indirect heating of the steam gasification reactor. After gas clean-up, the syngas was converted into heat, power and methanol or hydrogen production. Integrated gasification systems for production of energy and chemicals have been found economically feasible under the proper conditions of feedstock and product prices and economic and environmental policies [23]-[25]. Jatropha seed husk, with an elemental analysis in

Table 1 and a proximate analysis (in mass fraction) made up of moisture (10.75\%), volatile matter (63.40\%), fixed carbon $(22.30 \%)$ and ash $(3.54 \%)$, formed a basis for the estimation of the primary pyrolysis product yields as in [24]. The simulation was carried out for $91.4 \mathrm{Gg} \mathrm{y}^{-1}$ of seed husk resulting from the seeds processed into oil. The simulation flowsheets of the husk IBGCC plants for methanol (IBGCC-MeOH) or hydrogen $\left(\mathrm{IBGCC}-\mathrm{H}_{2}\right)$ production are shown in Fig. 5 and Fig. 6, respectively. Mass balances are shown in the Appendix. The equipment specifications are shown in Table 7. A water gas shift reactor (WGSR) was coupled to the gasifier to adjust the required syngas composition for methanol or hydrogen co-production. From a sensitivity study, a steam to biomass 
mass ratio of 0.34 was required in the case of methanol co-production and of 0.7 in the case of

261 hydrogen co-production. No additional steam was required for the WGSR.

262 Fig. 5 Simulation of Jatropha seed husk IBGCC-MeOH plant

263 Fig. 6 Simulation of Jatropha seed husk IBGCC-H $\mathrm{H}_{2}$ plant

264 The gas after removal of $\mathrm{H}_{2} \mathrm{~S}$ and $\mathrm{CO}_{2}$ was further conditioned to a stoichiometric number suitable 265 for methanol [23] as well as hydrogen-rich syngas production. The clean syngas was purified in a 266 pressure swing adsorption (PSA) unit for hydrogen production. The remaining syngas (i.e. after 267 meeting the demands for methanol or hydrogen as well as the off-gas streams from methanol and 268 hydrogen separation processes) were sent as fuels to the combustor. The off-gas from PSA was 269 compressed before feeding to the combustor (Fig. 6). A part of the combustion heat was used in the 270 gasifier and the rest was recovered into heat and power generation via steam.

\section{$271 \quad$ Table 7}

The methodology for heat integration and heat and power network design is shown in [23], [24]. The design procedure encompasses the pinch analysis for process to process heat recovery network design. Any excess heat is extracted into steam generation. The superheated steam generation must be maximised at the highest pressure level, such as very high pressure (VHP) steam. Thereafter, lower pressure superheated steam can be generated if heat is available at lower pressure level. To ensure feasible heat integration, minimum temperature difference between hot and cold streams must be maintained. The resulting heat and power design is shown in section 4 .

\subsubsection{Anaerobic digestion and biogas power}

280 Anaerobic digestion of Jatropha by-products and residues were modelled based on reported biogas 281 yields from literature in spreadsheets. The biogas production (with $\mathrm{CH}_{4}$ volume fraction of $70 \%$ ) of $0.546 \mathrm{Nm}^{3}$ from $1 \mathrm{~kg}$ of fruit shell [17] and $0.347 \mathrm{Nm}^{3}$ from $1 \mathrm{~kg}$ of dry cake [16] was taken as the basis. In the biodiesel system, $1 \mathrm{~kg}$ of glycerol was also digested into $0.306 \mathrm{~m}^{3}$ of $\mathrm{CH}_{4}$ (volume 284 fraction of methane in the biogas is 68.8\%) [19]. Note that these values are obtainable by optimising the process (e.g. $69.4 \%$ methane has been obtained from the cake by using an iron additive [58]). A 
$2 \%$ biogas loss due to leakage from digester was assumed and the GWP from the methane ( $25 \mathrm{~g}$

$\mathrm{CO}_{2}$-eq $\mathrm{g}^{-1} \mathrm{CH}_{4}$ ) has been taken into account. Biogas is used as fuel to generate electricity in a combined cycle with an efficiency of 50\%. Alternative 4 is used to show the previous considerations. The alternative 4 in the biodiesel system involves anaerobic digestion of Jatropha cake, fruit shells and glycerol and power production from the resulting biogas. About $98 \mathrm{Gg}^{-1}$ of biogas can be produced by digesting the three substrates. About $2 \mathrm{Gg} \mathrm{y}^{-1}\left(1.97 \times 10^{6} \mathrm{Nm}^{3} \mathrm{y}^{-1}\right)$ of biogas is lost. The GHG emissions in this biogas leakage are not completely balanced by the $\mathrm{CO}_{2}$ captured by the Jatropha plants because methane has a GWP of $25 \mathrm{~g} \mathrm{CO}_{2}-\mathrm{eq} \mathrm{g}^{-1}$. The total GWP from methane is $22.3 \mathrm{Gg} \mathrm{y}^{-1}$. However, the methane carbon $\left(0.68 \mathrm{Gg}_{\text {carbon }} \mathrm{y}^{-1}\right)$ is captured as $\mathrm{CO}_{2}$ by the Jatropha plants and corresponds to $2.5 \mathrm{Gg} \mathrm{CO}_{2} \mathrm{y}^{-1}$. Thus, there is a net GWP of $19.8 \mathrm{Gg}$ $\mathrm{CO}_{2}$-eq $\mathrm{y}^{-1}$ from the anaerobic digestion due to biogas leakage. The remaining $96 \mathrm{Gg} \mathrm{y}^{-1}\left(9.66 \times 10^{7}\right.$

$\mathrm{Nm}^{3} \mathrm{y}^{-1}$ ) of biogas contains about $2.43 \mathrm{PJ} \mathrm{y}^{-1}$ and is converted into $1.21 \mathrm{PJ} \mathrm{y}^{-1}$ of electricity generation. The waste heat from the biogas power plant is used to meet heating requirements of the digester and part of the electricity is used for pumping and stirring. The heat and power requirements are according to [20], assuming a $12 \%$ of substrate content in the slurry fed to the digester. The net exported electricity was $1.10 \mathrm{PJ} \mathrm{y}^{-1}$. In the integrated green diesel biorefinery system with alternative 4, the cake and shells were anaerobically digested. The GWP from anaerobic digestion was $18.9 \mathrm{Gg} \mathrm{CO}_{2}$-eq $\mathrm{y}^{-1}$. The resulting net exported electricity was $1.04 \mathrm{PJ} \mathrm{y}^{-1}$.

\section{Results and discussion - Jatropha cultivation and standalone systems}

\subsection{Jatropha cultivation}

Fig. 7 shows the resulting CPE and GWP impacts from Jatropha cultivation. The main contribution to the CPE impacts is from the manufacture of fertilisers, seed conditioning and storage. The GWP 308 impact is mainly contributed by the field emissions due to nitrogen fertilisation, manufacture of 309 fertilisers and seed conditioning. The cultivation system requires $0.14 \mathrm{PJ} \mathrm{y}^{-1}$ of diesel, $0.25 \mathrm{PJ} \mathrm{y}^{-1}$ of heat and $1970 \mathrm{GJ} \mathrm{y}^{-1}$ of power. The CPE and GWP impact allocations to seeds are 5.4 MJ_CPE kg$311{ }^{1}$ and $0.63 \mathrm{~kg} \mathrm{CO}_{2}$-eq $\mathrm{kg}^{-1}$, respectively. The CPE from Jatropha cultivation is 0.37 MJ_CPE $\mathrm{MJ}^{-1}$ 
312 and the GWP is $43.2 \mathrm{~g} \mathrm{CO}_{2}$-eq $\mathrm{MJ}^{-1}$ in the case of biodiesel energy. The CPE from Jatropha 313 cultivation is $0.34 \mathrm{MJ}$-CPE $\mathrm{MJ}^{-1}$ and the GWP is $40.0 \mathrm{~g} \mathrm{CO}_{2}$-eq $\mathrm{MJ}^{-1}$ in the case of green diesel 314 energy.

315 Fig. 7 Results of a) CPE and b) GWP impacts from Jatropha cultivation

\subsection{Stand-alone biodiesel and green diesel plants (base cases)}

317 The co-products from stand-alone biodiesel and green diesel plants are the extracted cake, glycerol 318 (in biodiesel plant) and propane fuel mix (PFM, in green diesel plant). The fossil-based equivalent 319 products are fuel oil for glycerol and liquefied petroleum gas (LPG) for PFM. In the case of cake 320 being used for animal feed, $1 \mathrm{~kg}$ of cake could replace $1.4 \mathrm{~kg}$ of soy meal according to protein 321 content comparisons [11]. The inventory and impact analyses for the various processes are discussed as follows.

$0.40 \mathrm{PJ}^{-1}$ of heat and $0.06 \mathrm{PJ}^{-1}$ of power were required for seed processing. The CPE from seed processing (a total of $0.78 \mathrm{PJ}_{\mathrm{CPE}} \mathrm{y}^{-1}$ ) was contributed by hexane by $5.2 \%$, natural gas for heat production (at $70 \%$ efficiency) by $75.1 \%$ and power by $19.7 \%$. The GWP (a total of $46.7 \mathrm{Gg} \mathrm{CO}_{2^{-}}$ eq $\mathrm{y}^{-1}$ ) contributions from these sources were $2 \%, 75.8 \%$ and $22.1 \%$ respectively.

The cradle-to-gate LCA results for the biodiesel standalone production system are presented in

Table 8. The GWP impact from biodiesel production was $43.3 \mathrm{~g} \mathrm{CO}_{2}$-eq $\mathrm{MJ}^{-1}$, leading to $42 \%$ saving in respect to diesel. The CPE per unit of energy in biodiesel was 0.51 MJ_CPE $\mathrm{MJ}^{-1}$, leading to $54 \%$ saving in respect to diesel. The operating energy efficiency, $E_{o p}=$ Energy output in all products / (Energy content in all feedstock + direct energy consumption) is $91 \%$.

\section{Table 8}

The LCA results for the cradle-to-gate green diesel standalone production system are presented in Table 8. A GWP of $39.9 \mathrm{~g} \mathrm{CO}_{2}$-eq $\mathrm{MJ}^{-1}$ was estimated for green diesel. This result is comparable to the value of $45.5 \mathrm{~g} \mathrm{CO}_{2}$-eq $\mathrm{MJ}^{-1}$ for green diesel from soybean oil reported in [7]. The resulting 336 GWP saving was $46 \%$. The CPE per unit of energy in green diesel was $0.56 \mathrm{MJ}$ CPE $\mathrm{MJ}^{-1}$, resulting in a saving of $52 \%$ with respect to diesel. About $85 \%$ of the CPE and GWP impacts 
resulted from the imported hydrogen (hydrogen is assumed to be produced from natural gas [48]).

339 Contribution from power generation to CPE and GWP impacts is $10.7 \%$ and $11.1 \%$, respectively. 340 The contribution from MP steam production is $3.2 \%$ to CPE and $2.9 \%$ to GWP. The rest is 341 contributed by LP steam production. Energy input is $0.02 \mathrm{PJ} \mathrm{y}^{-1}$ as heat, $0.03 \mathrm{PJ} \mathrm{y}^{-1}$ as power, 0.40 $342 \mathrm{PJ} \mathrm{y}^{-1}$ as hydrogen (High Heating Value (HHV)=141.8 $\left.\mathrm{MJ} \mathrm{kg}^{-1}\right)$ and $4.15 \mathrm{PJ} \mathrm{y}^{-1}$ as oil $(\mathrm{HHV}=39.63$ $\left.343 \mathrm{MJ} \mathrm{kg}^{-1}\right)$. The energy contained in green diesel $\left(\mathrm{HHV}=45.80 \mathrm{MJ} \mathrm{kg}^{-1}\right)$ is $4.28 \mathrm{PJ} \mathrm{y}^{-1}$ and in PFM $344\left(\mathrm{HHV}=46.26 \mathrm{MJ} \mathrm{kg}^{-1}\right)$ is $0.16 \mathrm{PJ} \mathrm{y}^{-1}$. Thus, the operating energy efficiency of Jatropha utilisation 345 in the process is $E_{o p}=96 \%$.

346 However, the overall system includes the energy required in cultivation (0.39 $\mathrm{PJ}^{-1}$ in Section 4.1), 347 seed processing $\left(0.47 \mathrm{PJ} \mathrm{y}^{-1}\right.$ in Section 4.2.1) as well as the energy wasted in seed husk (1.82 $\mathrm{PJ} \mathrm{y}^{-}$ $34{ }^{1}$ ), fruit shells $\left(2.11 \mathrm{PJ}^{-1}\right)$ and extraction cake $\left(1.37 \mathrm{PJ}^{-1}\right)$. By considering all this energy inputs, 349 the energy efficiency of the green diesel standalone plant is just $E_{o p}=4.44 / 10.76=41 \%$. Similar 350 calculations show that the energy efficiency of the biodiesel standalone plant is $39 \%$. These results 351 indicate a potential for improving the efficiency of Jatropha conversion for energy production in 352 both biofuel production systems.

353 4. Results and discussion - integrated biorefinery systems

$354 \quad 4.1$ Process integration for GWP and CPE reduction

355 The heat and power networks of the proposed schemes for Jatropha-based integrated biorefineries 356 were designed to meet the heat and methanol or hydrogen demands of the respective biofuel plants. 357 Any excess heat energy recovered via steam generation is converted into power generation 358 displacing the grid electricity. The resulting heat and power generation flowsheets are shown in Fig. $359 \mathbf{8}$ and described as follows:

360 Fig. 8 Heat and power network of husk processing into a) IBGCC-MeOH and b) IBGCC-H $_{2}$

361 - The steam levels were set by the temperature levels of the various processes. Very high 362 pressure (VHP) steam at $10 \mathrm{MPa}$ and $650{ }^{\circ} \mathrm{C}$, medium pressure (MP) steam at $1.5 \mathrm{MPa}$ and low 363 pressure (LP) steam at $0.5 \mathrm{MPa}$ were generated in both $\mathrm{IBGCC}-\mathrm{H}_{2}$ and $\mathrm{IBGCC}-\mathrm{MeOH}$ systems. 
- $\quad$ High pressure (HP) steam was generated at $3 \mathrm{MPa}$ and $650{ }^{\circ} \mathrm{C}$ by recovering heat from the gasifier product gas in a high recovery steam generator (HRSG1). In IBGCC-MeOH, the surplus HP steam, after meeting the gasifier steam requirement, was used in back-pressure steam turbine ST3. In IBGCC-H $\mathrm{H}_{2}$ plant, all the steam produced in HRSG1 was used in the gasifier.

- In both IBGCC systems, the heat in the flue gas from the combustor (COMBUSTR, at 1200

${ }^{\circ} \mathrm{C}$ ) was recovered into VHP steam generation in a high recovery steam generator (HRSG2). The same flue gas was further expanded in a turbo-expander (TEXP) to generate power for the air compressor (AIRCOMPR in Fig. 5 and Fig. 6). Thus surplus power was generated. In the integrated biodiesel system, the VHP steam generated in HRSG2 was first used to fulfil the heat requirement by the reboiler in the biodiesel recovery column before generating power from the back-pressure steam turbine ST1 (Fig. 8).

- The surplus exothermic heat of reaction of the combustor (COMBUSTR), after meeting the heat requirements of the gasifier, was also recovered into VHP steam generation. In the IBGCC- $\mathrm{H}_{2}$, 377 all the VHP steam generated from COMBUSTR and HRSG2 was expanded through the back378 pressure steam turbine (ST1) to an outlet pressure of $0.5 \mathrm{MPa}$ for power generation since there was 379 no demand for VHP steam in the green diesel plant.

- $\quad$ Excess heat from WGSR, SYNGCOOL and MEOHREAC (in IBGCC-MeOH plant) was 381 suitable for MP steam generation. In the green diesel and IBGCC- $\mathrm{H}_{2}$ integrated system, part of the 382 MP steam generated was used in the oil preheater (RMIXHTR, Fig. 4) and the excess was utilised 383 for power generation in back-pressure steam turbine (ST2). In the biodiesel and IBGCC-MeOH 384 integrated system, all the MP steam generated was used to fulfil the heat demands by the biodiesel 385 plant.

386 LP steam generated after expansion of steam at higher levels was used to meet heat demands 387 by the gas clean up and biodiesel or green diesel plants. Surplus LP steam was passed through 388 condensing steam turbine for power generation. The condensate was returned as boiler feed water. 
- The waste heat available in the syngas stream after heat recovery as MP steam in 390 SYNGCOOL (in both IBGCC- $\mathrm{H}_{2}$ and IBGCC-MeOH) and the methanol reactor product (in IBGCC-MeOH plant) was extracted to preheat the water used for steam generation.

The net energy from the IBGCC-MeOH plant (including waste heat and heat and power generation for other biorefinery processes) was $0.35 \mathrm{PJ} \mathrm{y}^{-1}$ as power, $0.16 \mathrm{PJ} \mathrm{y}^{-1}$ as heat and $0.26 \mathrm{PJ} \mathrm{y}^{-1}$ as methanol (HHV of $22.7 \mathrm{MJ} \mathrm{kg}^{-1}$ ). Thus, the operating energy efficiency of IBGCC-MeOH plant is $42.3 \%$, based on HHV of husk. Similarly, the net energy produced from IBGCC- $\mathrm{H}_{2}$ plant was 0.32 $\mathrm{PJ}^{-1}$ as power, $0.04 \mathrm{PJ}^{-1}$ as heat and $0.4 \mathrm{PJ} \mathrm{y}^{-1}$, as hydrogen. Thus, the operating energy efficiency of IBGCC- $\mathrm{H}_{2}$ plant is $41.8 \%$.

The CPE is reduced from 2.67 PJ_CPE $\mathrm{y}^{-1}$ in the standalone biodiesel production system to 2.15 PJ_CPE $\mathrm{y}^{-1}$ in the integrated system, resulting in further CPE saving by $19 \%$. The total GWP 400 impact (as) is reduced from $266.9 \mathrm{Gg} \mathrm{CO}_{2}$-eq y $\mathrm{y}^{-1}$ to $211.2 \mathrm{Gg} \mathrm{CO}_{2}$-eq $\mathrm{y}^{-1}$ (21\% reduction) in the integrated biorefinery compared to standalone biodiesel production system. The CPE is reduced from 2.89 PJ_CPE $\mathrm{y}^{-1}$ in the standalone green diesel production system to 2.15 PJ_CPE $\mathrm{y}^{-1}$ in the integrated system, resulting in CPE saving by $25 \%$. The total GWP impact (as $\mathrm{CO}_{2}$-eq) is reduced from $258.9 \mathrm{Gg} \mathrm{y}^{-1} \mathrm{CO}_{2}$-eq to $211.2 \mathrm{Gg} \mathrm{y}^{-1} \mathrm{CO}_{2}$-eq (18\% reduction) in the integrated biorefinery 405 compared to standalone green diesel production system.

406 An excess power of $0.28 \mathrm{PJ} \mathrm{y}^{-1}$ in the biodiesel system and $0.23 \mathrm{PJ} \mathrm{y}^{-1}$ in the green diesel system 407 can be exported to grid. Using the system expansion approach to consider the credits from the substitution of equivalent fossil-based products (i.e. fuel oil substituted by glycerol, soy meal by seed cake and grid electricity by electricity from the biorefinery system), the net CPE and GWP savings are determined. The CPE and GWP savings from biodiesel with respect to fossil based 411 diesel are increased to $95 \%$ and $72 \%$. The corresponding CPE and GWP savings from green diesel with respect to diesel are increased to $92 \%$ and $70 \%$, respectively.

413 The integrated biorefinery systems are self-sufficient to supply energy and methanol or hydrogen by 414 on-site production. The CPE and GWP savings are similar in both biofuel systems. There are 
greater savings from replacement of methanol, and especially heat and power in the integrated biodiesel system. However, the green diesel system is more suitable for integration with crude oilbased refinery infrastructure and might receive further support especially from crude oil companies.

\subsection{Alternatives for whole Jatropha fruit utilisation}

The results of total CPE and GWP of the systems studied are shown in Figure 9 for the functional unit of $1 \mathrm{MJ}$ of biofuel energy output. The standalone plants are taken as the base case for comparison. The integrated systems (indicated as Int) correspond to the strategic integration of biofuel plants with husk utilisation in IBGCC systems. The integrated systems combined with options for the utilisation of cake, shells and glycerol are indicated as Int-1 to Int-5. The net values are the sum of the impacts incurred and the credits obtained from the exported co-products due to substitution of fossil products.

Biodiesel systems are environmentally more benign than green diesel systems. This is mainly due to the higher avoided impact from displacement of fossil-based methanol in the biodiesel plant than from fossil-based hydrogen displacement in the green diesel plant. In addition, the credits from grid electricity substitution are lower in the green diesel system due to lower electricity generation.

In Int-1, the use of cake to provide heat allowed avoiding the impacts from the use of natural gas in seed processing and diesel for seed drying (within the cultivation system), otherwise. The fruit shell as fuel in Int- 2 brings the same benefits as the cake in Int- 1 . This allows the utilisation of the cake as fertiliser in Int-2 and as animal feed in Int-3. However, alternative 3 achieves lower GWP than Int-2 and even negative CPE, because of the substitution of soy meal by Jatropha cake. Int-1 to Int3 produce the same total bioenergy output of $4.44 \mathrm{PJ} \mathrm{y}^{-1}$ in the biodiesel system and of $4.67 \mathrm{PJ} \mathrm{y}^{-1}$ in the green diesel system. In both biofuel systems, the CPE and GWP change from positive values to negative values when the power plant using biogas from anaerobic digestion is considered in Int4 and 5.

Fig. 9 GWP and CPE results of biodiesel ( $a$ and b, respectively) and green diesel (c and d, respectively) in the base case (standalone plants), integrated biorefinery systems (Int) and the integrated biorefinery systems with the five alternatives (Int-1 to Int-5). BC: base case; BPP: biogas power plant; IBGCC: integrated biomass gasification and combined cycle. 
443 Int-4 utilises Jatropha by-products (cake, shell, glycerol) to generate electricity using anaerobic 444 digestion. The substitution of grid electricity by electricity generation using biogas resulted in 445 further CPE savings and GWP reduction. The total bioenergy production in the biodiesel system is $4465.33 \mathrm{PJ} \mathrm{y}^{-1}$ while the green diesel system produces $5.71 \mathrm{PJ} \mathrm{y}^{-1}$. However, as shown in Fig. 9, more 447 benefits in terms of CPE and GWP savings are obtained in Int-5. Int-5 assumes that the cake is used 448 to produce heat for oil extraction and seed drying while fruit shells and glycerol (biodiesel system) 449 are anaerobically digested to generate electricity via biogas. In this integrated biodiesel system, 5.05 $450 \mathrm{PJ} \mathrm{y}^{-1}$ of output energy is generated in the form of biodiesel, heat and power. The total input energy 451 is $9.45 \mathrm{PJ} \mathrm{y}^{-1}$ from Jatropha fruit fractions and $0.14 \mathrm{PJ} \mathrm{y}^{-1}$ from diesel used in field operations 452 during cultivation, yielding an energy efficiency of 53\%. This is an increase by $14 \%$ from the 453 Jatropha oil conversion to biodiesel in the standalone (base case) process. In the green diesel 454 system, the output energy is $5.43 \mathrm{PJ} \mathrm{y}^{-1}$ in the form of green diesel, propane fuel, heat and power 455 output from the same total input energy as in the biodiesel system. The resulting energy efficiency 456 is $57 \%$. This is $16 \%$ more efficient than the Jatropha oil conversion to green diesel in the standalone 457 process. The two integrated biofuel systems in Int-5 exhibit an energy yield per unit of land of 83 458 GJ ha ${ }^{-1}$. The GWP from the net bioenergy production (i.e. the energy actually exported in the form 459 of biofuels and electricity) is $160 \mathrm{Gg} \mathrm{CO}_{2}-\mathrm{eq} \mathrm{y}^{-1}$ in both systems. Thus, the average GWP per unit 460 of bioenergy output is $29 \mathrm{~g} \mathrm{CO}_{2}$-eq $\mathrm{MJ}^{-1}$. This GWP value is before accounting credits from 461 substitution of fossil-based energy by the energy co-produced and exported from the biorefineries. 462 After accounting for the credits from displacement of grid electricity, the CPE saving is $138 \%$ and 463 GWP reduction is $110 \%$ in the biodiesel system, while the CPE saving is $133 \%$ and GWP reduction 464 is $108 \%$ in the green diesel system, respectively (in Int-5). These savings are more than two-folds 465 compared to the standalone systems. These imply that, although it might not be possible to 466 completely de-carbonise the biofuel supply chains upstream (e.g. in the cultivation stage where 467 extensive fertilisation is required to increase yields), the impacts can be counterbalanced by whole 468 crop conversion into useful products in integrated biorefinery systems such as Int-5. 


\section{Conclusions}

Comprehensive system modelling, simulation, integration and analysis tools have been applied to generate integrated biorefinery configurations aimed at high efficiency biofuel and energy productions and fossil resource saving and low global warming potential impact. The low energy efficiency of the standalone biofuel systems can be improved by converting the whole fruit into energy and raw material productions. The raw materials are used up by the biofuel production processes. This is achieved by on-site production of heat and power, methanol or hydrogen using husk gasification. The strategic utilisation of seed husk in IBGCC systems has been explored for reduction in GWP and CPE. In addition, potential benefits from the use of Jatropha cake as fuel or animal feed are also explored. The GWP savings are favoured by the utilisation of cake as animal feed, whilst its utilisation as fuel favours CPE savings. The benefits of integration of anaerobic digestion of Jatropha fruit shells, cake and/or glycerol producing biogas used for power generation has also been demonstrated. Results showed that energy and GHG emissions saving could be doubled in an integrated Jatropha biorefinery exploiting the whole Jatropha fruit, compared to the standalone plants only converting the Jatropha oil into biofuel production.

The methodological contributions from this paper are heat integration, total site utility system design and synergetic material product integration. These methodological contributions made in this paper allowed the substitution of fossil energy and major raw materials used for the biofuel production processes and thereby savings in GWP and CPE. The use of shells and glycerol for electricity production via anaerobic digestion combined with any of the potential uses of cake (as fuel, fertiliser, for animal feed or also as substrate for anaerobic digestion) increased the savings considerably. This led to zero or even negative CPE and GWP due to significant credits obtained from the substitution of fossil products by the biorefinery products. The credits achievable are more than to offset the impacts by the system. The two biofuel systems studied had very similar performance regarding GWP and CPE savings. The systems are evaluated for future implementation by assuming optimum parameters for Jatropha cultivation and conversion 
processes. A sensitivity analysis and the use of other allocation approaches may be needed for application of the results.

497 Although integrated systems showed environmental and energetic advantages, practicality and economic feasibility studies must be carried out to allow a holistic selection of the best Jatrophabased integrated biorefinery configuration. Biofuel properties and their adaptation to existing 500 infrastructure as well as uncertainties in prices, economic incentives and policy support need to be 501 evaluated. Furthermore, the capital required to build the various processing plants might involve 502 more than one investor and might require further incentives for cooperation to operate as a whole 503 integrated system. The processing capacity scale also needs to be optimised considering the 504 previous aspects.

Acknowledgement

507 Financial support from CONACYT of Mexico and EPSRC (EP/F063563/1 and EP/F063563/2) of 508 the UK for undertaking this research is gratefully acknowledged.

\section{References}

510 [1] Wahl N, Hildebrandt T, Moser C, Lüdeke-Freund F, Averdunk K (2012) Insights into 511 Jatropha Projects Worldwide Key Facts \& Figures from a Global Survey. Leuphana University of 512 Lüneburg, Lüneburg (Germany).

513 [2] Devappa RK., Makkar HPS, Becker K (2010) Optimization of conditions for the extraction of 514 phorbol esters from Jatropha oil. Biomass Bioenergy, 34(8):1125-1133

515 [3] Hamarneh AI, Heeres HJ, Broekhuis AA, Picchioni F. (2010) Extraction of Jatropha curcas 516 proteins and application in polyketone-based wood adhesives. Int J Adhes Adhes 30(7):615-625

517 [4] Misailidis N., Campbell GM, Du C., Sadhukhan J, Mustafa M, Mateos-Salvador F, Weightman 518 RM (2009) Evaluating the feasibility of commercial arabinoxylan production in the context of a 519 wheat biorefinery principally producing ethanol. Part 2. Process simulation and economic analysis. 520 Chem Eng Res Des 87, 1239-1250. 
[5] Achten WMJ, Verchot L, Franken YJ, Mathijs E, Singh VP, Aerts R, Muys B (2008)

522 Jatropha bio-diesel production and use. Biomass Bioenergy 32(12):1063-1084

523 [6] Huaping Z, Zongbin W, Yuanxiong C, Ping Z, Shijie D, Xiaohua L, Zongqiang M (2006)

524 Preparation of biodiesel catalyzed by solid super base of calcium oxide and its refining process.

525 Chinese J Catal 27(5):391-396

526 [7] Huo H, Wang M, Bloyd C, Putsche V (2008) Life-cycle assessment of energy and 527 greenhouse gas effects of soybean-derived biodiesel and renewable fuels. 528 http://www.transportation.anl.gov/pdfs/AF/467.pdf. Accessed 25 February 2013

529 [8] Singh RN, Vyas DK, Srivastava NSL, Narra M. (2008) SPRERI experience on holistic 530 approach to utilize all parts of Jatropha curcas fruit for energy. Renew Energ 33(8):1868-1873

531 [9] Rivera-Lorca JA, Ku-Vera JC (1997) Chemical composition of three different varieties of $J$. 532 curcas from Mexico. In: Gubitz GM, Mittelbach M, and Trabi M, editors. Biofuels and industrial 533 products from Jatropha curcas. Jatropha Symposium, Feb 23-Feb 27 1997; Managua, Nicaragua. 534 Technische Universität Graz, Graz (Austria), pp 47-52

535 [10] Martinez-Herrera J, Siddhuraju P, Francis G, Davila-Ortiz G, Becker K (2006) Chemical 536 composition, toxic/antimetabolic constituents, and effects of different treatments on their levels, in 537 four provenances of Jatropha curcas L. from Mexico. Food Chem 96(1):80-89

538 [11] Makkar HPS, Becker K (1997) Potential of J. curcas seed meal as a protein supplement to 539 livestock feed. Constraints to its utilisation and possible strategies to overcome constraints. In: 540 Gubitz GM, Mittelbach M, and Trabi M, editors. Biofuels and industrial products from Jatropha 541 curcas. Jatropha Symposium, Feb 23-Feb 27 1997; Managua, Nicaragua. Technische Universitat 542 Graz, Graz (Austria), pp 190-205

543 [12] FACT Foundation (2010). The Jatropha handbook. $\underline{\text { http://www.fact- }}$ 544 foundation.com/en/Knowledge_and_Expertise/Handbooks?session=crv4nn46ndd6jhpcarlf9kg4b1.

545 Accessed February 2013 
[13] Makkar HPS, Martinez-Herrera J, Becker K (2008) Variations in seed number per fruit, seed

547 physical parameters and contents of oil, protein and phorbol ester in toxic and non-toxic genotypes 548 of Jatropha curcas. J Plant Sc 3(4):260-265

549 [14] Heller J (1996) Physic nut Jatropha curcas L. Promoting the conservation and use of 550 underutilized and neglected crops. Institute of Plant Genetics and Crop Plant Research, Gatersleben 551 / International Plant Genetic Resources Institute, Rome

552 [15] Jongschaap REE, Corre WJ, Bindraban PS, Brandenburg WA (2007) Claims and facts on 553 Jatropha curcas L.: Global Jatropha curcas evaluation, breeding and propagation programme. 554 Plant Research International BV, Wageningen (Netherlands)

555 [16] Staubmann R, Foidl G, Foidl N, Gubitz GM, Lafferty RM, Arbizu VM, Steiner W (1997) 556 Biogas production from Jatropha curcas press cake. Appl Biochem Biotech 63-65(1):457-467

557 [17] Lopez O, Foidl G, Foidl N (1997) Production of Biogas from J. curcas Fruit shells. In: 558 Gubitz GM, Mittelbach M, and Trabi M, editors. Biofuels and industrial products from Jatropha 559 curcas. Jatropha Symposium, Feb 23-Feb 27 1997; Managua, Nicaragua. Technische Universitat 560 Graz, Graz (Austria), pp 118-122

561 [18] Dhanya MS, Gupta N, Joshi HC, Lata (2009) Biogas potentiality of agro-wastes Jatropha 562 fruit coat. Int J Civil Environ Eng 1(3):136-140

563 [19] Lopez J, Santos M, Perez A, Martin A (2009) Anaerobic digestion of glycerol derived from 564 biodiesel manufacturing. Bioresource Technol 100(23):5609-5615

565 [20] Thamsiriroj T, Murphy JD (2010) Can rape seed biodiesel meet the European Union 566 sustainability criteria for biofuels? Energy Fuels 24(3):1720-1730

567 [21] Manurung R, Wever DAZ, Wildschut J, Venderbosch RH, Hidayat H, van Dam JEG, 568 Leijenhorst EJ, Broekhuis AA, Heeres HJ (2009) Valorisation of Jatropha curcas L. parts: Nut shell 569 conversion to fast pyrolysis oil. Food Bioprod Process 87(3):187-196

570 [22] Sricharoenchaikul V, Atong D (2009) Thermal decomposition study on Jatropha curcas L. 571 waste using TGA and fixed bed reactor. J Anal Appl Pyrol 85(1-2):155-162 
[23] Ng KS, Sadhukhan J (2011) Process integration and economic analysis of bio-oil platform

573 for the production of methanol and combined heat and power. Biomass Bioenergy 35(3):1153-1169

574 [24] Sadhukhan J, Ng KS, Shah N, Simons HJ (2009) Heat integration strategy for economic 575 production of combined heat and power from biomass waste. Energy Fuels 23(10):5106-5120

576 [25] Sadhukhan J, Ng KS (2011) Economic and European Union environmental sustainability 577 criteria assessment of bio-oil based biofuel systems: Refinery integration cases. Ind Eng Chem Res $578 \quad 50(11): 6794-6808$

579 [26] Pfeifer C, Koppatz S, Hofbauer H (2011) Steam gasification of various feedstocks at a dual 580 fluidised bed gasifier: Impacts of operation conditions and bed materials. Biomass Conv Bioref $581 \quad 1(1): 39-53$

582 [27] Wagner H, Kaltschmitt M (2012) Biochemical and thermochemical conversion of wood to 583 ethanol-simulation and analysis of different processes. Biomass Conv Bioref. 584 doi:10.1007/s13399-012-0064-0

585 [28] Jahan MS, Sultana N, Rahman M, Quaiyyum A (2012) An integrated biorefinery initiative 586 in producing dissolving pulp from agricultural wastes. Biomass Conv Bioref. doi: 10.1007/s13399$587 \quad 012-0067-x$

588 [29] Pollex A, Ortwein A, Kaltschmitt M (2012) Thermo-chemical conversion of solid biofuels. 589 Biomass Conv Bioref 2(1):21-39

590 [30] Boldrin A, Balzan A, Astrup T (2013) Energy and environmental analysis of a rapeseed 591 biorefinery conversion process. Biomass Conv Bioref. doi:10.1007/s13399-013-0071-9

592 [31] Weinberg J, Kaltschmitt M, Wilhelm C (2012) Analysis of greenhouse gas emissions from 593 microalgae-based biofuels. Biomass Conv Bioref 2(2):179-194

594 [32] Reinhardt G, Gartner S, Rettenmaier N, Munch J, Falkenstein E (2007) Screening life cycle 595 assessment of Jatropha biodiesel. Institute for Energy and Environmental Research Heidelberg, 596 Heidelberg (Germany). $\quad$ http://www.ifeu.de/landwirtschaft/pdf/jatropha_report_111207.pdf. $597 \quad$ Accessed 25 Feb 2013 
[33] Achten WMJ, Almeida J, Fobelets V, Bolle E, Mathijs E, Singh VP, Tewari DN, Verchot

599 LV, Muys B (2010) Life cycle assessment of Jatropha biodiesel as transportation fuel in rural India. 600 Appl Energ 87(12):3652-3660

601 [34] Ndong R, Montrejaud-Vignoles M, Saint-Girons O, Gabrielle B, Pirot R, Domergue M, 602 Sablayrolles C (2009) Life cycle assessment of biofuels from Jatropha curcas in West Africa: a 603 field study. Glob Change Biol Bioenergy (3):197-210

604 [35] Prueksakorn K, Gheewala SH (2006). Energy and greenhouse gas implications of biodiesel 605 production from Jatropha curcas L. Proceedings of the $2^{\text {nd }}$ Joint International Conference on 606 Sustainable Energy and Environment, Nov 21-Nov 23 2006; Bangkok, Thailand. 607 http://www.jatropha.pro/pdf\%20bestanden/ghg\%20thailand.pdf. Accessed 25 Feb 2013

608 [36] Linnhoff B (1993) Pinch Analysis -A state of the art overview. Trans IchemE 71(A):503$609 \quad 522$

610 [37] Wang YP, Smith R (1994) Wastewater minimisation. Chem Eng Sci 49(7):981-1006

611 [38] Majozi T, Brouckaert CJB, Buckley CAB (2006). A graphical technique for wastewater 612 minimisation in batch processes. J Environ Manage 78(4):317-329

613 [39] Ng DKS, Pham V, El-Halwagi MM, Jiménez-Gutiérrez A, Spriggs HD (2010) A 614 hierarchical approach to the synthesis and analysis of integrated biorefineries. In: El-Halwagi MM, 615 Linninger AA, editors. Design for Energy. Proceedings of the Seventh International Conference on 616 Foundations of Computer- Aided Process Design, June 7-Jun 12 2009; Breckenridge, CO (US). 617 CRC Press, Florida(US), pp 425-432

618 [40] Kokossis AC, Yang A (2010) On the use of systems technologies and a systematic approach 619 for the synthesis and the design of future biorefineries. Comput Chem Eng 34(9):1397-1405

620 [41] El-Halwagi MM (1997) Pollution prevention through process integration: Systematic design 621 tools, $1^{\text {st }}$ edn. Academic Press, San Diego

622 [42] Dunnett A, Adjiman C, Shah N (2007) Biomass to heat supply chains: Applications of 623 process optimization. Process Saf Environ 85(5):419-429 
624 [43] Hosseini SA, Shah N (2011) Multiscale Modeling of Biorefineries. Comput Aided Chem 625 Eng 29:1688-1692

626 [44] Aspen Technology, Inc. (2013) www.aspentech.com/products/aspen-plus.aspx. Accessed 25 $627 \quad$ Feb 2013

628 [45] Williams AG, Audsley E, Sandars DL (2006) Determining the environmental burdens and 629 resource use in the production of agricultural and horticultural commodities. Cranfield University 630 and DEFRA, Bedford $\quad$ (UK). 631 http://www.cranfield.ac.uk/sas/naturalresources/research/projects/is0205.html. Accessed 25 Feb $632 \quad 2013$

633 [46] Melgarejo-Flores LA, Palmerin-Ruiz E, Magdaleno-Molina M, Gasca-Ramirez J, Sosa634 Iglesias G, Vega-Rangel E, Sánchez-Reyna G, Rivero-Rodríguez R (2008) Integración del 635 inventario para análisis de ciclo de vida en la producción de petrolíferos de la refinería Miguel 636 Hidalgo. Presented at: International Eco-efficiency Forum 2008. Instituto Mexicano del Petroleo, 637 Coatzacoalcos (Mexico). http://www.scribd.com/doc/14424951/Pres-8. Accessed 25 Feb 2013

638 [47] Beer T, Grant T, Morgan G, Lapszewicz J, Anyon P, Edwards J (2001) Comparison of 639 transport fuels. Stage 2 study of life-cycle emissions analysis of alternative fuels for heavy vehicles. 640 Australian $\quad$ Greenhouse $\quad$ Office, $\quad$ Aspendale $\quad$ (Australia). 641 http://www.globalbioenergy.org/uploads/media/06_Australian_Greenhouse_Office_642 _Comparison_of_Transport_Fuels.pdf. Accessed 25 Feb 2013

643 [48] Spath PL, Mann MK (2001). Life cycle assessment of hydrogen production via NG steam 644 reforming. National Renewable Energy Laboratory, Golden, Colorado (US). 645 http://www.nrel.gov/docs/fy01osti/27637.pdf. Accessed 25 Feb 2013

646 [49] Dalgaard R, Schmidt J, Halberg N, Christensen P, Thrane M, Pengue WA (2008). LCA of 647 soybean meal. Int J LCA 13(3):240-254

648 [50] SENER, Mexico (2013) Sistema de Información Energética; www.sener.org.mx. Accessed $64925 \mathrm{Feb} 2013$ 
651 Global mapping of Jatropha curcas yield based on response of fitness to present and future climate.

652 Glob Change Biol Bioenergy 2:139-151

653 [52] Angulo-Escalante MA (2010) Clones de Jatropha curcas altamente productivos. Resultados 654 de proyectos de investigación, validación y transferencia de tecnología 2009-2010. Fundación 655

Produce Sinaloa

A.C., $\quad$ Sinaloa

(Mexico),

$\mathrm{pp}$

$136-139$.

656 http://www.fps.org.mx/divulgacion/index.php?option=com_remository \&Itemid=284\&func=select\& $\underline{\mathrm{id}=1}$. Accessed 25 February 2013

[53] Kalannavar VN (2008) Response of Jatropha curcas to nitrogen, phosphorus and potassium

levels in northern transition zone of Karnataka. Dissertation, University of Agricultural Sciences,

660 Dharwad (India)

661 [54] Ouwens DK, Francis G, Franken YJ, Rijssenbeek W, Riedacker R, Foidl N, Jongschaap R, 662 Bindraban P (2007) Position Paper on Jatropha curcas, State of the Art, Small and Large Scale 663

Project

Development.

FACT

Foundation,

The

Netherlands.

664 http://www.betuco.be/agroforestry/Jatropha\%20-

\%20Paper\%20on\%20Jatropha\%20and\%20Large\%20Scale\%20Project\%20Development.pdf.

666 Accessed October 2013.

667 [55] Prueksakorn K, Gheewala SH, Malakul P, Bonnet S (2010) Energy analysis of Jatropha 668 plantation systems for biodiesel production in Thailand. Energ Sust Dev 14(1):1-5

669 [56] Adriaans T (2006) Suitability of solvent extraction for Jatropha curcas. FACT Foundation, 670 The Netherlands. $\quad$ http://www.fact-foundation.com/media_en/FACT_\%282006\%29_671 Suitability_of_solvent_extraction_for_jatropha_curcas. Accessed 25 Feb 2013

672 [57] Chang A, Liu YA (2010) Integrated process modeling and product design of biodiesel 673 manufacturing. Ind Eng Chem Res 49(3):1197-1213

674 [58] Schmidt T (2011) Anaerobic digestion of Jatropha curcas L. press cake and effects of an iron675 additive. Waste Manag Res 29:1171-1176 
Table 1 Elemental analysis, compositions and calorific values of various Jatropha products

\begin{tabular}{lcccccc}
\hline & \multicolumn{2}{c}{ FRUIT } & \multicolumn{2}{c}{ SEED } & \multicolumn{2}{c}{ KERNEL } \\
& Shell $^{\mathbf{a}}$ & Seed $^{\mathbf{b}, \mathbf{d}}$ & Husk $^{\mathbf{c}, \mathbf{g h}}$ & Kernel $^{\mathbf{d}, \mathbf{g}}$ & Oil $^{\mathbf{e}}$ & Cake $^{\mathbf{f}, \mathbf{h}}$ \\
\hline Mass (\%) & 31.0 & 69.0 & 33.7 & 66.3 & 58.2 & 41.8 \\
$\mathrm{C}$ & 32.52 & 60.71 & 48.5 & 66.92 & 77.40 & 52.3 \\
$\mathrm{H}$ & & 8.19 & 5.7 & 9.46 & 11.58 & 6.5 \\
$\mathrm{O}$ & & 25.33 & 41.0 & 17.35 & 11.01 & 26.18 \\
$\mathrm{~N}$ & 3.64 & 1.67 & 0.67 & 2.17 & & 4.81 \\
$\mathrm{~S}$ & 0.02 & 0.16 & 0.01 & 0.24 & & 0.58 \\
$\mathrm{P}$ & 0.76 & & & & & 2.23 \\
K & 4.93 & & & & & 1.5 \\
Ash & 14.88 & 3.93 & 4.08 & 3.86 & & 9.24 \\
HHV (MJ kg & 17.28 & 27.1 & 19.9 & 30.9 & 39.6 & 18.3
\end{tabular}

677 a. Mass fraction in the fruit calculated after [12]. P and $\mathrm{K}$ values are part of the ash fraction. Elemental 678 composition from [8], [18]; $\mathrm{H}$ and $\mathrm{O}$ not reported. Heating value from [8].

679 b. Mass fraction in the fruit calculated after [12].

680 c. Elemental composition from [21].

681 d. Elemental composition and heating value calculated by mass and energy balance, respectively.

682 e. Oil fraction in kernel is at an average oil extraction efficiency of $99.1 \%$ by solvent method. Efficiency derived 683 from [10]. Heating value from [5]. Elemental composition from simulation results.

684 f. Elemental composition determined from [15], [22]. $\mathrm{P}$ and $\mathrm{K}$ are part of the ash fraction.

685 g. Average mass fraction calculated from [9], [10], [11] and [13].

686 h. Average heating value calculated from [9], [10], [11] and [13].

687 i. HHV: high heating value 
699

700 
701 Table 2 CPE and GWP factors for materials and energy used or produced in the various Jatropha 702 subsystems

\begin{tabular}{|c|c|c|c|c|}
\hline Item & $\begin{array}{c}\text { Functional } \\
\text { unit }\end{array}$ & $\begin{array}{c}\text { CPE } \\
\text { (MJ_CPE) }\end{array}$ & $\begin{array}{c}\text { GWP } \\
\left(\mathrm{g} \mathrm{CO}_{2} \text {-eq) }\right.\end{array}$ & Reference \\
\hline $\mathrm{N}$ fertiliser (Urea) & $\mathrm{kg}$ & 49.25 & 2940 & [45] \\
\hline P fertiliser (Triple superphosphate) & $\mathrm{kg}$ & 18.81 & 1160 & {$[45]$} \\
\hline $\mathrm{K}$ fertiliser & $\mathrm{kg}$ & 5.6 & 380 & [45] \\
\hline Machinery (manufacturing and storage) & $\mathrm{h}$ & 40.81 & 2.912 & {$[45]$} \\
\hline Storage buildings & $\mathrm{m}^{2} \mathrm{y}$ & 51.69 & 4.721 & [45] \\
\hline Abamectin (pesticide) & $\mathrm{L}$ & 190 & 13.12 & [45] \\
\hline Glyphosate (herbicide) & $\mathrm{L}$ & 190 & 13.12 & [45] \\
\hline Diesel & MJ & 1.114 & 74.4 & [46] \\
\hline Electricity mix & MJ & 2.597 & 173.4 & $\begin{array}{l}\text { Estimated } \\
\text { from [50] }\end{array}$ \\
\hline Natural gas (NG) & MJ & 1.016 & 61.2 & [45] \\
\hline Liquefied petroleum gas (LPG) & MJ & 1.06 & 76.4 & [47] \\
\hline Fuel Oil & MJ & 1.11 & 94.9 & [45] \\
\hline Hexane & $\mathrm{kg}$ & 37.5 & 861 & [7] \\
\hline Methanol & $\mathrm{kg}$ & 12.872 & 2836 & [33] \\
\hline Hydrogen & $\mathrm{kg}$ & 183.2 & 11888 & [48] \\
\hline Soy meal & $\mathrm{kg}$ & 4.13 & 726 & [49] \\
\hline
\end{tabular}


Table 3 Reported measured yields of Jatropha plantations in different locations and estimated annual seed yield at maturity [12], [14], [51], [52]

\begin{tabular}{|c|c|c|c|c|}
\hline Location & $A A R(\mathbf{m m})$ & Age, $A(y)$ & $\begin{array}{l}\text { Reported yield at } \\
\text { age } A, Y_{A}(\mathrm{~kg} / \mathrm{ha})\end{array}$ & $\begin{array}{c}\text { Yield at } \\
\text { maturity, } Y_{m}(\mathrm{~kg} / \mathrm{ha})\end{array}$ \\
\hline Bawal, India & 521 & 3 & 208 & 300 \\
\hline Jaipur, India & 668 & 2.5 & 313 & 500 \\
\hline Erode, India & 693 & 2.5 & 350 & 550 \\
\hline Kapiri Mposhi, Zambia & 744 & 2.5 & 500 & 780 \\
\hline Nashik, India & 690.5 & 5 & 1200 & 1200 \\
\hline Hyderabad, India & 812.5 & 3 & 911 & 1400 \\
\hline Digini, Mali & 1020 & 2 & 550 & 1500 \\
\hline Andhra Prades, India h & 925 & 2.5 & 1000 & 1680 \\
\hline Surubaya, Indonesia & 1751 & 2 & 1000 & 1950 \\
\hline Sinaloa, Mexico & 600 & 2 & 980 & 1966 \\
\hline Tamil Nadu, India & 945 & 3 & 1573 & 2000 \\
\hline Allahabad, India & 998 & 4 & 2000 & 2300 \\
\hline Bhavnagar, India & 800 & 2 & 1270 & 2400 \\
\hline Tirunelveli, India & 736.9 & 3 & 2000 & 2600 \\
\hline Leon, Nicaragua & 1593 & 4 & 2500 & 2750 \\
\hline Managua, Nicaragua & 1200 & 4 & 3484 & 3915 \\
\hline Paraguay & 1370 & 8 & 4000 & 4000 \\
\hline Sinaloa, Mexico & 1453 & 2 & 2040 & 4092 \\
\hline Thailand & 1470 & 1 & 794 & 5456 \\
\hline Maximum & 1500 & & & 5000 \\
\hline
\end{tabular}


709 Table 4 Inventory data for Jatropha cultivation in the location under study

\begin{tabular}{ll}
\hline Inventory & Amount input \\
\hline N fertiliser & $162 \mathrm{~kg} / \mathrm{ha}$ \\
P fertiliser & $162 \mathrm{~kg} / \mathrm{ha}$ \\
K fertiliser & $162 \mathrm{~kg} / \mathrm{ha}$ \\
Machinery & $2 \mathrm{~h} / \mathrm{ha}, 42.6 \mathrm{~kW}$ tractor \\
Diesel & $6584 \mathrm{MJ} / \mathrm{ha}$ \\
Electricity from grid & $27.8 \mathrm{MJ} / \mathrm{ha}$ \\
Storage area & $3.7 \mathrm{~m} / \mathrm{ha}$ \\
Abamectin (pesticide) & $2 \mathrm{~L} / \mathrm{ha}$ \\
Glyphosate (herbicide) & $2 \mathrm{~L} / \mathrm{ha}$
\end{tabular}

710

711

712

713

714

715

716

717

718 
719 Table 5 Specifications for the biodiesel simulation in Aspen Plus

\begin{tabular}{|c|c|c|c|c|c|c|}
\hline Equipment & Model & $\mathbf{T}\left({ }^{\circ} \mathbf{C}\right)$ & $\mathbf{P}(\mathbf{k P a})$ & Other specifications & & Reference \\
\hline RMIXHTR & Heater & 70 & 101.3 & & & [6] \\
\hline \multirow[t]{2}{*}{ TEREACT } & Rstoic & 70 & 101.3 & Tryglycerides conversion fraction & 0.93 & [6] \\
\hline & & & & Free fatty acids conversion fraction & 1 & Assumed \\
\hline \multirow[t]{4}{*}{ MEOHREC } & RadFrac & & 40 & Pressure drop (bar) & 0.1 & Assumed \\
\hline & & & & Stages & 16 & From simulation \\
\hline & & & & Methanol mass recovery $(\%)$ & 99 & Specified \\
\hline & & & & Molar reflux ratio & 2 & From simulation \\
\hline RECPUMP & Pump & & 200 & & & \\
\hline COOL1 & Heater & 25 & 101.3 & & & \\
\hline DECANT & Decanter & 25 & 101.3 & & & \\
\hline \multirow[t]{3}{*}{ BIODREC } & RadFrac & & 101.3 & Stages & 4 & From simulation \\
\hline & & & & FAME mass recovery $(\%)$ & 99 & Specified \\
\hline & & & & Molar reflux ratio & 0.2 & From simulation \\
\hline PREH1 & Heater & & 101.3 & Duty (MW) & 2.27 & From simulation \\
\hline PREH1-1 & Heater & 35 & 101.3 & & & Specified \\
\hline COOL2 & Heater & 35 & 101.3 & & & Specified \\
\hline
\end{tabular}


723 Table 6 Specifications for the green diesel simulation in Aspen Plus [7]

\begin{tabular}{|c|c|c|c|c|c|}
\hline Equipment & Model & $\mathbf{T}\left({ }^{\circ} \mathbf{C}\right)$ & $\mathbf{P}(\mathbf{k P a})$ & Other specifications & \\
\hline HE1 & HeatX & & & Hot Stream Outlet $\mathrm{T}\left({ }^{\circ} \mathrm{C}\right)$ & 275 \\
\hline RMIXHTR & Heater & 188 & 3450 & & \\
\hline \multirow[t]{6}{*}{ H2TRECTR } & RYield & 325 & 3450 & Mass yield fractions: & \\
\hline & & & & GDIESEL & 0.8415 \\
\hline & & & & PROPANE & 0.0290 \\
\hline & & & & WATER & 0.0213 \\
\hline & & & & $\mathrm{CO}_{2}$ & 0.1063 \\
\hline & & & & $\mathrm{H}_{2}$ & 0.0020 \\
\hline OILPUMP & Pump & & 3450 & Isentropic efficiency & 0.85 \\
\hline PHASESEP & Flash2 & 35 & 1200 & Free water phase valid & \\
\hline \multirow[t]{5}{*}{ PSA } & Sep & & & $\begin{array}{l}\text { Component mass split } \\
\text { fraction: }\end{array}$ & \\
\hline & & & & $\mathrm{CO}_{2}$ in stream $\mathrm{CO} 2$ & 1 \\
\hline & & & & PROPANE in stream CO2 & 0 \\
\hline & & & & $\mathrm{H}_{2}$ in stream H2RECVD & 1 \\
\hline & & & & Others in stream H2RECVD & 0 \\
\hline \multirow[t]{2}{*}{ GDISLREC } & RadFrac & & 101.3 & Stages & 8 \\
\hline & & & & No condenser, no reboiler & \\
\hline LPGSEP & Flash2 & 20 & 101.3 & Free water phase valid & \\
\hline H2FCOMPR & Compresor & & 3450 & Isentropic efficiency & 0.85 \\
\hline H2RCOMPR & Compresor & & 3450 & Isentropic efficiency & 0.85 \\
\hline
\end{tabular}


Table 7 Specifications for the simulation of husk conversion into heat, power and methanol or 741 hydrogen via gasification

\begin{tabular}{|c|c|c|c|c|c|}
\hline Name & Model & $\mathbf{T}\left({ }^{\circ} \mathbf{C}\right)$ & $\mathbf{P}(\mathbf{M P a})$ & Other specifications & \\
\hline AIRCOMPR & Compr & & 3 & Isentropic efficiency & 0.85 \\
\hline MPRODEXP & Compr & & 4.1 & Isentropic efficiency & 0.9 \\
\hline OFFGCOMP & Compr & & 3 & Isentropic efficiency & 0.85 \\
\hline \multirow[t]{2}{*}{ B1 } & Fsplit & & & Flow rate $\left(\mathrm{t} \mathrm{d}^{-1}\right)$ for steam to biomass & 94.93 \\
\hline & & & & $\begin{array}{l}\text { ratin }-\cap 25 \text { in IRFCr }-\mathrm{Ma} \cap \mathrm{MH} \\
\text { Mass split fraction in IBGCC- } \mathrm{H}_{2}\end{array}$ & 1 \\
\hline B5 & Flash2 & 55 & 0.1 & & \\
\hline RECWPUMP & Pump & & 3 & Isentropic efficiency & 0.85 \\
\hline B19 & Fsplit & & & Mass split fraction & 0.2384 \\
\hline COMBUSTR & RGibbs & 1200 & 3 & (IBGCC-MeOH) & \\
\hline CYCLONE & SSplit & & & Ash mass split fraction & 1 \\
\hline EFFLUSEP & Flash2 & 55 & 3 & & \\
\hline \multirow[t]{2}{*}{ GCLEANUP } & Sep2 & 55 & 3 & $\mathrm{CO}_{2}$ mass split fraction & 0.9 \\
\hline & & & & $\mathrm{H}_{2} \mathrm{~S}$ and $\mathrm{COS}$ mass fraction & 1 \\
\hline HRSG1 & HeatX & & & Hot stream outlet $\mathrm{T}\left({ }^{\circ} \mathrm{C}\right)$ & 450 \\
\hline MEOHREAC & Requil & 250 & 10 & & \\
\hline MEOHREC & Flash2 & 55 & 3 & & \\
\hline STGASIFY & RGibbs & 1100 & 3 & & \\
\hline SYNGCOMP & Compr & & 10 & Isentropic efficiency & 0.85 \\
\hline SYNGCOOL & Heater & 55 & 3 & & \\
\hline WGSR & Requil & 450 & 3 & & \\
\hline \multirow[t]{2}{*}{ PSA } & Sep & & & $\mathrm{H}_{2}$ mass split fraction & 0.8 \\
\hline & & & 0.1 & OFFGAS stream flash pressure & \\
\hline
\end{tabular}


Table 8 LCA results for the biodiesel and green diesel standalone systems for the calculation basis of $104.7 \mathrm{Gg} \mathrm{y}^{-1}$ of Jatropha oil and for the functional unit of $1 \mathrm{MJ}$ of biofuel

\begin{tabular}{|c|c|c|c|c|c|c|}
\hline & $\begin{array}{c}\text { Mass flow } \\
\left(\text { Gg y }^{-1}\right)\end{array}$ & $\begin{array}{l}\text { Energy } \\
\left(\mathbf{P J} \mathbf{y}^{-1}\right)\end{array}$ & $\begin{array}{c}\text { CPE } \\
\left(\begin{array}{c}\text { PJ_CPE } \\
\left.\mathbf{y}^{-1}\right)\end{array}\right. \\
\end{array}$ & $\begin{array}{c}\text { GWP } \\
\left(\mathrm{Gg} \mathrm{CO}_{2^{-}}\right. \\
\left.\mathrm{eq}^{-1}\right)\end{array}$ & $\begin{array}{c}\text { CPE } \\
\left(\mathbf{M J}_{-} \mathbf{C P E}\right. \\
\left.\mathbf{M J}^{-1}\right)\end{array}$ & $\begin{array}{c}\text { GWP } \\
\left(\mathrm{g} \mathrm{CO}_{2} \text {-eq }\right. \\
\left.\mathrm{MJ}^{-1}\right)\end{array}$ \\
\hline \multicolumn{7}{|l|}{ Biodiesel system } \\
\hline Total before credits & 100.0 & 3.96 & 2.67 & 266.9 & 0.675 & 67.4 \\
\hline Net glycerol credit & 10.7 & 0.20 & -0.23 & -19.3 & -0.058 & -4.9 \\
\hline Net cake credit & 75.1 & & -0.43 & -76.4 & -0.109 & -19.3 \\
\hline $\begin{array}{l}\text { Net to biodiesel } \\
\text { Green diesel system }\end{array}$ & & & 2.0 & 171.5 & 0.51 & 43.3 \\
\hline Total before credits & 93.4 & 4.28 & 2.89 & 258.9 & 0.675 & 60.49 \\
\hline Net propane fuel credit & 3.4 & 0.16 & -0.17 & -12.0 & -0.040 & -2.8 \\
\hline Net cake credit & 75.1 & & -0.43 & -76.3 & -0.101 & -17.8 \\
\hline Net to green diesel & & & 2.29 & 170.6 & 0.53 & 39.9 \\
\hline
\end{tabular}


767 Table 9 Mass balance of the biodiesel plant

\begin{tabular}{|c|c|c|c|c|c|c|c|c|c|c|}
\hline Mass fraction & JATROOIL & METHANOL & REACMIX & TERPROD & RECMETOH & GLYCFAME & CRUDEFAME & CRUDGLYC & BIODIESEL & OILWASTE \\
\hline 3OLEN & 0.4500 & 0 & 0.3512 & 0.0246 & 0.1171 & 0.0029 & 0.0032 & 0 & 0.0002 & 0.0590 \\
\hline 3PALMITI & 0.1140 & 0 & 0.0833 & 0.0058 & 0 & 0.0072 & 0.0079 & 0 & 0.0 & 0.1582 \\
\hline 3LINLEN & 0.4030 & 0 & 0.2946 & 0.0206 & 0 & 0.0255 & 0.0281 & 0 & 0.0 & 0.5592 \\
\hline 3STEARIN & 0.0227 & 0 & 0.0166 & 0.0012 & 0 & 0.0014 & 0.0016 & 0 & 0.0 & 0.0315 \\
\hline OL日C-01 & 0.0103 & 0 & 0.0075 & 0 & 0 & 0 & 0 & 0 & 0.0 & 0.0 \\
\hline M-OLEATE & 0 & 0 & 0 & 0.3360 & 0 & 0.4149 & 0.4571 & 0 & 0.4769 & 0.0827 \\
\hline MPALMTTE & 0 & 0 & 0 & 0.0779 & 0 & 0.0962 & 0.1060 & 0 & 0.1093 & 0.0423 \\
\hline MLINLEAT & 0 & 0 & 0 & 0.2752 & 0 & 0.3399 & 0.3744 & 0 & 0.3918 & 0.0447 \\
\hline MSTEARAT & 0 & 0 & 0 & 0.0155 & 0 & 0.0191 & 0.0211 & 0 & 0.0211 & 0.0215 \\
\hline METHANOL & 0 & 1.0000 & 0.2466 & 0.1694 & 0.8823 & 0.0021 & 0.0006 & 0.0169 & 0.0006 & 0.0 \\
\hline GLYCEROL & 0 & 0 & 0 & 0.0731 & 0 & 0.0903 & 0.0001 & 0.9779 & 0.0 & 0.0010 \\
\hline WATER & 0 & 0 & 0.0001 & 0.0006 & 0.0006 & 0.0006 & 0.0001 & 0.0052 & 0.0001 & 0.0 \\
\hline Mass flow $\left(\mathrm{kg} \mathrm{h}^{-1}\right)$ & 13218 & 1426 & 18081 & 18081 & 3437 & 14644 & 13293 & 1351 & 12626 & 667 \\
\hline Molar flow $\left(\mathrm{km} \mathrm{ol} \mathrm{h}^{-1}\right)$ & 15.46 & 44.50 & 155.18 & 155.18 & 95.23 & 59.95 & 44.50 & 15.45 & 43.43 & 1.07 \\
\hline
\end{tabular}

769 Table 10 Mass balance of the green diesel plant

\begin{tabular}{|c|c|c|c|c|c|c|c|c|c|c|c|c|c|c|}
\hline Mass fraction & JATROOIL & H2FRESH & H2TOREAC & H2TRPROD & PRODGAS & CRUDGDSL & LPSTEAM & GREANDSL & $\mathrm{CO} 2$ & LIGHTEND & PROPANE & VENT & WATER & WATER2 \\
\hline 3OLEN & 0.4500 & 0 & 0 & 0 & 0 & 0 & 0 & 0 & 0 & 0 & 0 & 0 & 0 & 0 \\
\hline 3PALMITI & 0.1140 & 0 & 0 & 0 & 0 & 0 & 0 & 0 & 0 & 0 & 0 & 0 & 0 & 0 \\
\hline 3LINLEN & 0.4030 & 0 & 0 & 0 & 0 & 0 & 0 & 0 & 0 & 0 & 0 & 0 & 0 & 0 \\
\hline 3STEARIN & 0.0227 & 0 & 0 & 0 & 0 & 0 & 0 & 0 & 0 & 0 & 0 & 0 & 0 & 0 \\
\hline OL日C-01 & 0.0103 & 0 & 0 & 0 & 0 & 0 & 0 & 0 & 0 & 0 & 0 & 0 & 0 & 0 \\
\hline GDIESEl & 0 & 0 & 0 & 0.8415 & 0 & 0.9771 & 0 & 0.9708 & 0 & 0 & 0 & 0.9686 & 0 & 0 \\
\hline PROPANE & 0 & 0 & 0 & 0.0290 & 0.1049 & 0.0192 & 0 & 0 & 0 & 0.6376 & 0.9194 & 0.0307 & 0 & 0 \\
\hline WATER & 0 & 0 & 0 & 0.0213 & 0.0029 & 0.0011 & 1.0000 & 0.0292 & 0 & 0.2761 & 0.0097 & 0.0007 & 1.0000 & 1.0000 \\
\hline $\mathrm{CO} 2$ & 0 & 0 & 0 & 0.1063 & 0.8753 & 0.0026 & 0 & 0 & 1.0000 & 0.0863 & 0.0709 & 0 & 0 & 0 \\
\hline $\mathrm{H} 2$ & 0 & 1.0000 & 1.0000 & 0.0020 & 0.0168 & 0 & 0 & 0 & 0 & 0 & 0 & 0 & 0 & 0 \\
\hline Mass flow $\left(\mathrm{kg} \mathrm{h}^{-1}\right)$ & 13218 & 360 & 387 & 13605 & 1617 & 11717 & 372 & 11793 & 1415 & 353 & 429 & 0 & 271 & 42 \\
\hline Molar flow $\left(\mathrm{kmol} \mathrm{h}^{-1}\right)$ & 15.46 & 178.35 & 191.85 & 116.32 & 49.76 & 51.52 & 20.65 & 64.08 & 32.15 & 11.20 & 9.87 & 0.00 & 15.05 & 2.32 \\
\hline
\end{tabular}


772 Table 11 Mass balance of husk gasification and methanol production in the IBGCC-MeOH plant

\begin{tabular}{|c|c|c|c|c|c|c|c|c|c|c|c|c|c|c|c|c|c|c|c|c|}
\hline Mass fraction & CHARIN & GASIN & TARIN & 2-GASPDT & ASH & WGSRPROD & RECYCH2O & PURGEH2O & STEAMIN2 & DRYSYNG & $\mathrm{CO} 2+\mathrm{H} 2 \mathrm{~S}$ & 8-CLNSYN & SYNGFUEL & SYNGAS & MEOHPROD & MOFFGAS & COMBGAS & AIRIN & 14-BFW & SHEATSTM \\
\hline $\mathrm{H} 2 \mathrm{O}$ & 0 & 0.1667 & 0.1428 & 0.1564 & 0 & 0.0498 & 0.9597 & 0.0567 & 0.9955 & 0.0065 & 0 & 0.0105 & 0.0105 & 0.0105 & 0.0027 & 0.0001 & 0.1304 & 0 & 1 & 0.9955 \\
\hline N2 & 0 & 0.0129 & 0 & 0.0046 & 0 & 0.0047 & 0 & 0.0007 & 0 & 0.0050 & 0 & 0.0081 & 0.0081 & 0.0081 & 0.0004 & 0.0328 & 0.6770 & 0.7671 & 0 & 0 \\
\hline 02 & 0 & 0 & 0.2983 & 0 & 0 & 0 & 0 & 0 & 0 & 0 & 0 & 0 & 0 & 0 & 0 & 0 & 0.0205 & 0.2329 & 0 & 0 \\
\hline NO2 & 0 & 0 & 0 & 0 & 0 & 0 & 0 & 0 & 0 & 0 & 0 & 0 & 0 & 0 & 0 & 0 & $4.56 \mathrm{E}-06$ & 0 & 0 & 0 \\
\hline NO & 0 & 0 & 0 & 0 & 0 & 0 & 0 & 0 & 0 & 0 & 0 & 0 & 0 & 0 & 0 & 0 & 0.0003 & 0 & 0 & 0 \\
\hline$s$ & 0 & 0 & 0 & 0 & 0 & 0 & 0 & 0 & 0 & 0 & 0 & 0 & 0 & 0 & 0 & 0 & 0 & 0 & 0 & 0 \\
\hline SO2 & 0 & 0 & 0 & 0 & 0 & 0 & 0 & 0 & 0 & 0 & 0 & 0 & 0 & 0 & 0 & 0 & 0 & 0 & 0 & 0 \\
\hline $\mathrm{SO} 3$ & 0 & 0 & 0 & 0 & 0 & 0 & 0 & 0 & 0 & 0 & 0 & 0 & 0 & 0 & 0 & 0 & 0 & 0 & 0 & 0 \\
\hline H2 & 0 & 0.0033 & 0 & 0.0589 & 0 & 0.0730 & 0 & 0 & 0 & 0.0772 & 0 & 0.1253 & 0.1253 & 0.1253 & 0 & 0.1399 & 0 & 0 & 0 & 0 \\
\hline c & 1 & 0 & 0 & 0 & 0 & 0 & 0 & 0 & 0 & 0 & 0 & 0 & 0 & 0 & 0 & 0 & 0 & 0 & 0 & 0 \\
\hline co & 0 & 0.4486 & 0 & 0.6095 & 0 & 0.4539 & 0.0003 & 0.0896 & 0 & 0.4790 & 0 & 0.7776 & 0.7776 & 0.7776 & 0.0066 & 0.4805 & 0 & 0 & 0 & 0 \\
\hline $\mathrm{CO} 2$ & 0 & 0.0639 & 0 & 0.1380 & 0 & 0.4130 & 0.0397 & 0.8455 & 0.0045 & 0.4266 & 0.9998 & 0.0692 & 0.0692 & 0.0692 & 0.0427 & 0.2400 & 0.1718 & 0 & 0 & 0.0045 \\
\hline $\mathrm{H} 2 \mathrm{~S}$ & 0 & 0.0002 & 0 & 0.0001 & 0 & 0.0001 & 0 & 0.0002 & 0 & 0.0001 & 0.0002 & 0 & 0 & 0 & 0 & 0 & 0 & 0 & 0 & 0 \\
\hline $\mathrm{CH} 4$ & 0 & 0.0500 & 0 & 0.0053 & 0 & 0.0055 & 0 & 0.0073 & 0 & 0.0057 & 0 & 0.0093 & 0.0093 & 0.0093 & 0.0031 & 0.0291 & 0 & 0 & 0 & 0 \\
\hline $\cos$ & 0 & 0 & 0 & 0 & 0 & 0 & 0 & 0 & 0 & 0 & 0 & 0 & 0 & 0 & 0 & 0 & 0 & 0 & 0 & 0 \\
\hline ETHAN-01 & 0 & 0.2544 & 0 & 0 & 0 & 0 & 0 & 0 & 0 & 0 & 0 & 0 & 0 & 0 & 0 & 0 & 0 & 0 & 0 & 0 \\
\hline PHENO-01 & 0 & 0 & 0.4879 & 0 & 0 & 0 & 0 & 0 & 0 & 0 & 0 & 0 & 0 & 0 & 0 & 0 & 0 & 0 & 0 & 0 \\
\hline METHANOL & 0 & 0 & 0 & 0 & 0 & 0 & 0 & 0 & 0 & 0 & 0 & 0 & 0 & 0 & 0.9445 & 0.0777 & 0 & 0 & 0 & 0 \\
\hline ASH & 0 & 0 & 0.0710 & 0.0272 & 1 & 0 & 0 & 0 & 0 & 0 & 0 & 0 & 0 & 0 & 0 & 0 & 0 & 0 & 0 & 0 \\
\hline Mass flow $\left(\mathrm{kg} \mathrm{h}^{-1}\right)$ & 443 & 5336 & 5764 & 15056 & 409 & 14647 & 658 & 134 & 3956 & 13854 & 5320 & 8534 & 6500 & 2035 & 1549 & 485 & 62589 & 55162 & 5188 & 1891 \\
\hline Molar flow $\left(\mathrm{kmol} \mathrm{h}^{-1}\right)$ & 36.84 & 215.63 & 129.30 & 953.07 & & 953.07 & 35.69 & 3.50 & 218.99 & 913.88 & 120.88 & 793.00 & 603.95 & 189.05 & 48.09 & 47.28 & 2250.66 & 1912.00 & 288.00 & 104.69 \\
\hline
\end{tabular}


781 Table 12 Mass balance of husk gasification and hydrogen production in the IBGCC- $\mathrm{H}_{2}$ plant

\begin{tabular}{|c|c|c|c|c|c|c|c|c|c|c|c|c|c|c|c|c|c|c|c|}
\hline Mass fraction & CHARIN & GASIN & TARIN & 2-GASPDT & ASH & WGSRPROD & RECYCH2O & PURGEH2O & STEAMIN2 & DRYSYNG & $\mathrm{CO}+\mathrm{H} 2 \mathrm{~S}$ & 8-CLNSYN & SYNGFUEL & SYNGAS & HYDROGEN & OFFGAS & COMBGAS & AIRIN & 14-BFW \\
\hline $\mathrm{H} 2 \mathrm{O}$ & 0 & 0.1667 & 0.1428 & 0.2895 & 0 & 0.1465 & 0.9553 & 0.0543 & 0.9848 & 0.0064 & 0 & 0.0153 & 0.0153 & 0.0153 & 0 & 0.0183 & 0.1463 & 0 & 1 \\
\hline N2 & 0 & 0.0129 & 0 & 0.0036 & 0 & 0.0037 & 0 & 0.0004 & 0 & 0.0045 & 0 & 0.0110 & 0.0110 & 0.0110 & 0 & 0.0131 & 0.6845 & 0.7671 & 0 \\
\hline 02 & 0 & 0 & 0.2983 & 0 & 0 & 0 & 0 & 0 & 0 & 0 & 0 & 0 & 0 & 0 & 0 & 0 & 0.0204 & 0.2329 & 0 \\
\hline NO2 & 0 & 0 & 0 & 0 & 0 & 0 & 0 & 0 & 0 & 0 & 0 & 0 & 0 & 0 & 0 & 0 & 4.54E-06 & 0 & 0 \\
\hline No & 0 & 0 & 0 & 0 & 0 & 0 & 0 & 0 & 0 & 0 & 0 & 0 & 0 & 0 & 0 & 0 & 0.0003 & 0 & 0 \\
\hline $\mathrm{s}$ & 0 & 0 & 0 & 0 & 0 & 0 & 0 & 0 & 0 & 0 & 0 & 0 & 0 & 0 & 0 & 0 & 0 & 0 & 0 \\
\hline SO2 & 0 & 0 & 0 & 0 & 0 & 0 & 0 & 0 & 0 & 0 & 0 & 0 & 0 & 0 & 0 & 0 & 0 & 0 & 0 \\
\hline $\mathrm{SO} 3$ & 0 & 0 & 0 & 0 & 0 & 0 & 0 & 0 & 0 & 0 & 0 & 0 & 0 & 0 & 0 & 0 & 0 & 0 & 0 \\
\hline $\mathrm{H} 2$ & 0 & 0.0033 & 0 & 0.0516 & 0 & 0.0695 & 0 & 0 & 0 & 0.0859 & 0 & 0.2069 & 0.2069 & 0.2069 & 1.0000 & 0.0496 & 0 & 0 & 0 \\
\hline c & 1 & 0 & 0 & 0 & 0 & 0 & 0 & 0 & 0 & 0 & 0 & 0 & 0 & 0 & 0 & 0 & 0 & 0 & 0 \\
\hline co & 0 & 0.4486 & 0 & 0.4278 & 0 & 0.2049 & 0.0001 & 0.0315 & 0 & 0.2515 & 0 & 0.6060 & 0.6060 & 0.6060 & 0 & 0.7263 & 0 & 0 & 0 \\
\hline $\mathrm{H} 2 \mathrm{~S}$ & 0 & 0.0002 & 0 & 0.0001 & 0 & 0.0001 & 0 & 0.0001 & 0 & 0.0001 & 0.0001 & 0 & 0 & 0 & 0 & 0 & 0 & 0 & 0 \\
\hline $\mathrm{CH} 4$ & 0 & 0.0500 & 0 & 0.0014 & 0 & 0.0015 & 0 & 0.0015 & 0 & 0.0017 & 0 & 0.0041 & 0.0041 & 0.0041 & 0 & 0.0049 & 0 & 0 & 0 \\
\hline $\cos$ & 0 & 0 & 0 & 0 & 0 & 0 & 0 & 0 & 0 & 0 & 0 & 0 & 0 & 0 & 0 & 0 & 0 & 0 & 0 \\
\hline ETHAN-01 & 0 & 0.2544 & 0 & 0 & 0 & 0 & 0 & 0 & 0 & 0 & 0 & 0 & 0 & 0 & 0 & 0 & 0 & 0 & 0 \\
\hline PHENO-01 & 0 & 0 & 0.4879 & 0 & 0 & 0 & 0 & 0 & 0 & 0 & 0 & 0 & 0 & 0 & 0 & 0 & 0 & 0 & 0 \\
\hline METHANOL & 0 & 0 & 0 & 0 & 0 & 0 & 0 & 0 & 0 & 0 & 0 & 0 & 0 & 0 & 0 & 0 & 0 & 0 & 0 \\
\hline ASH & 0 & 0 & 0.0710 & 0.0214 & 1 & 0 & 0 & 0 & 0 & 0 & 0 & 0 & 0 & 0 & 0 & 0 & 0 & 0 & 0 \\
\hline Mass flow $\left(\mathrm{kg} \mathrm{h}^{-1}\right)$ & 443 & 5336 & 5764 & 19099 & 409 & 18690 & 2717 & 851 & 7999 & 15123 & 8848 & 6275 & 4093 & 2182 & 361 & 1821 & 58287 & 51931 & 5283 \\
\hline Molar flow $\left(\mathrm{kmol} \mathrm{h}^{-1}\right)$ & 36.84 & 215.63 & 129.30 & 1180.73 & 0.00 & 1180.73 & 146.81 & 21.25 & 440.06 & 1012.67 & 201.05 & 811.61 & 529.39 & 282.23 & 179.19 & 103.04 & 2132.08 & 1800.00 & 293.27 \\
\hline
\end{tabular}




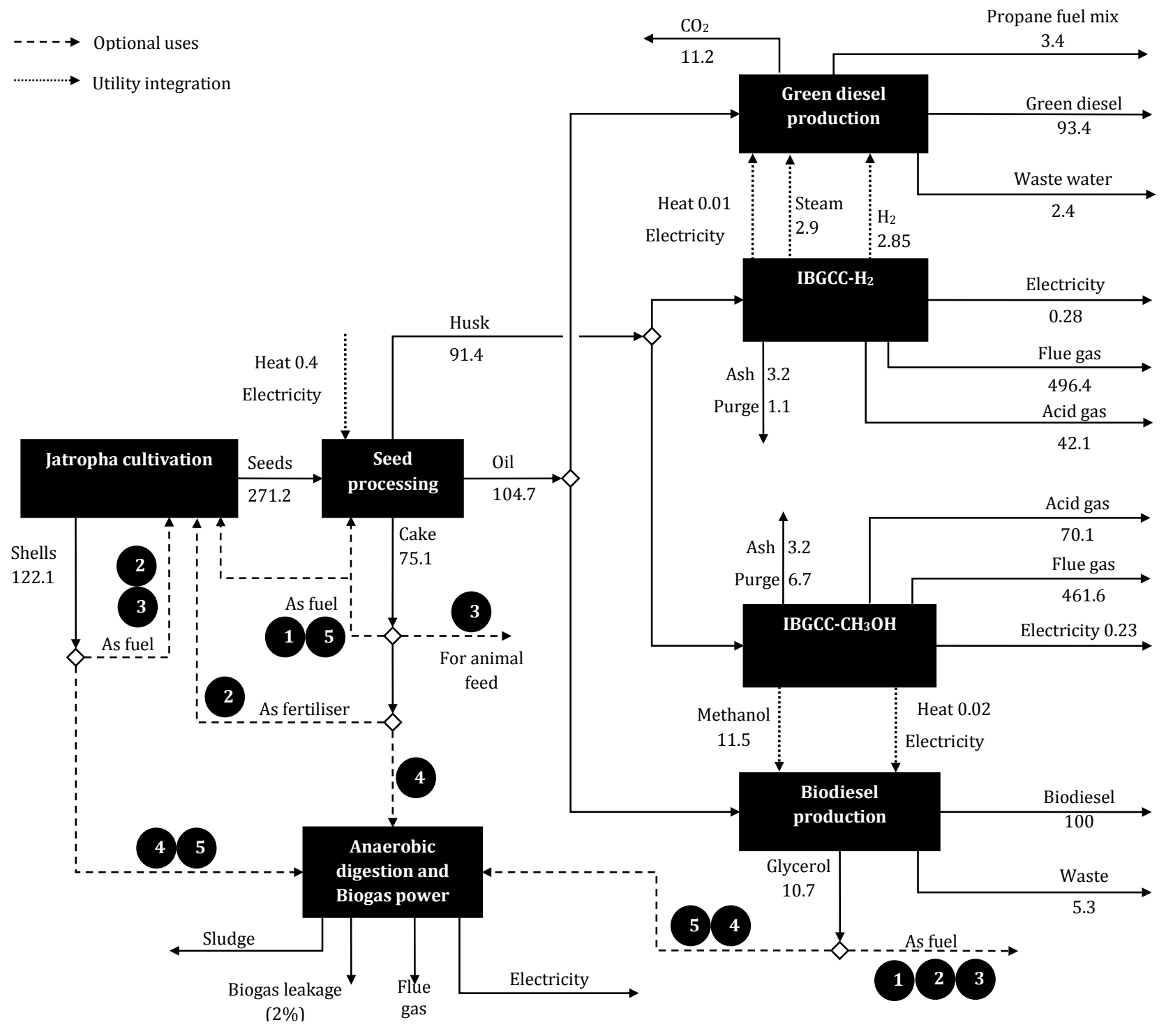

Fig. 1 


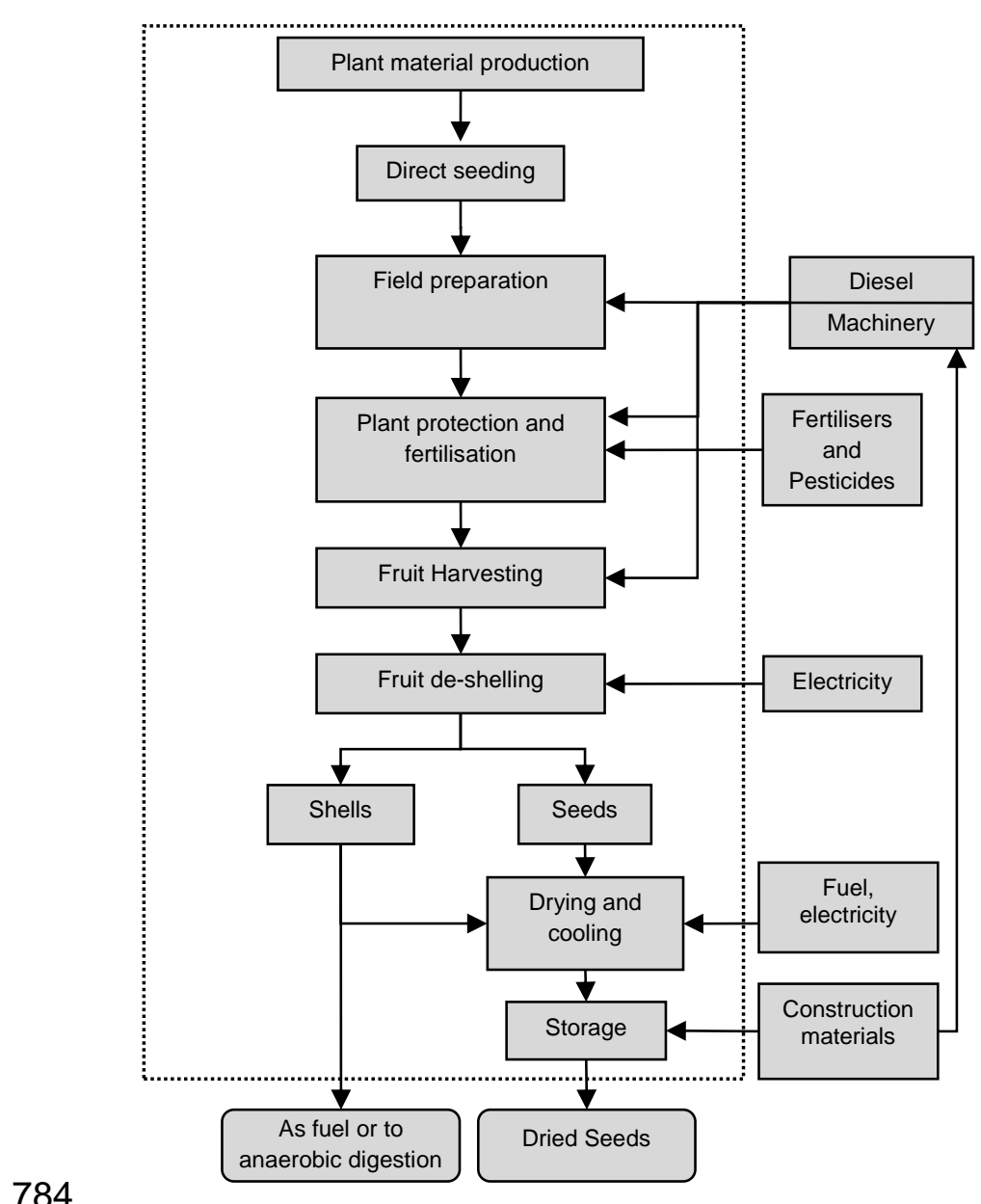

$785 \quad$ Fig. 2 


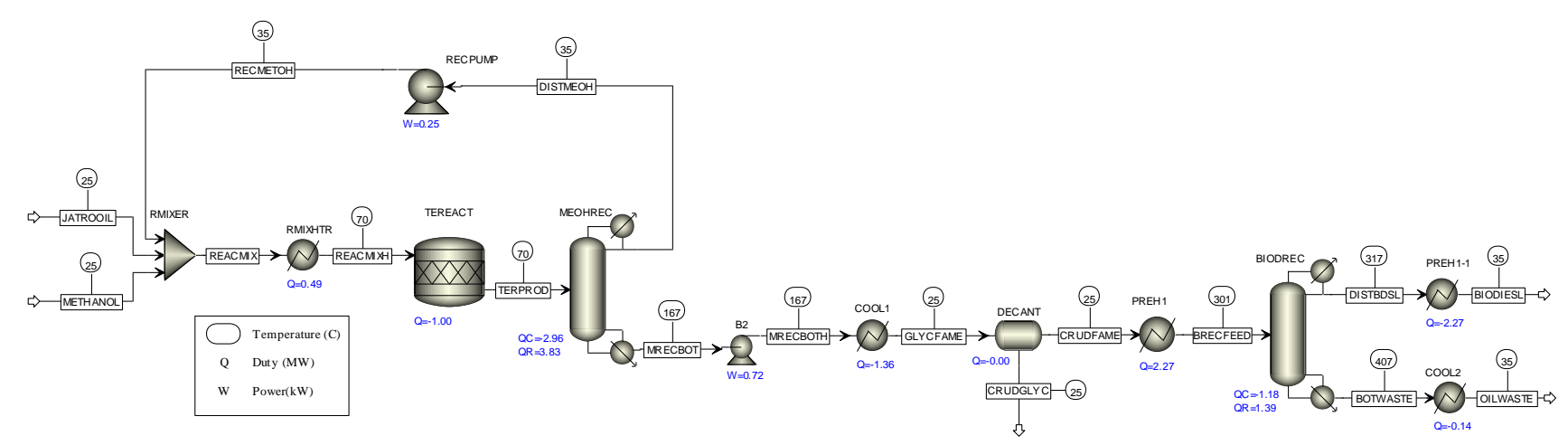

$789 \quad$ Fig. 3 


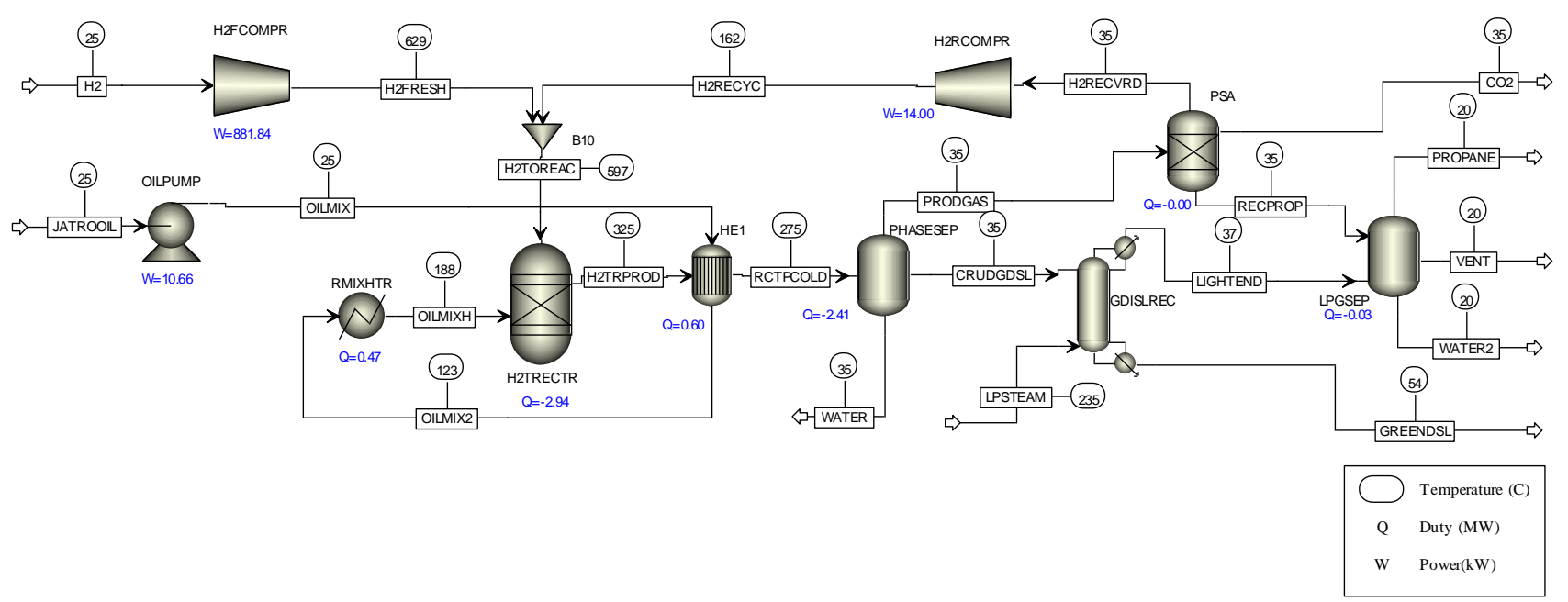

790

$791 \quad$ Fig. 4 


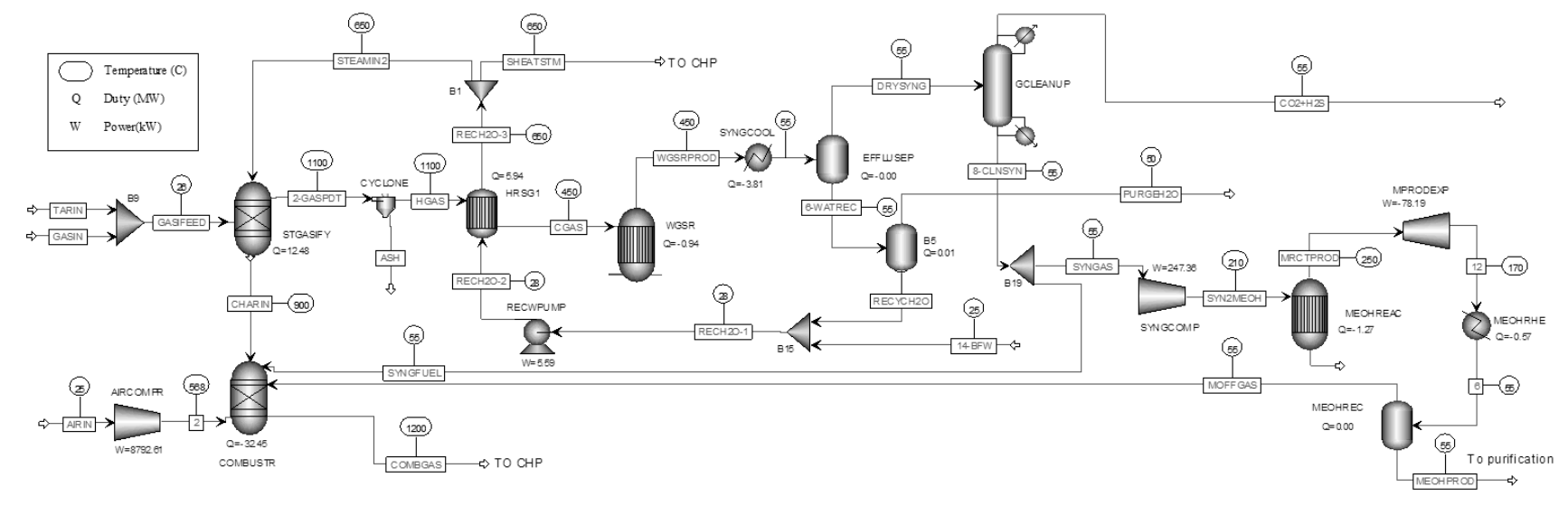

794 Fig. 5 


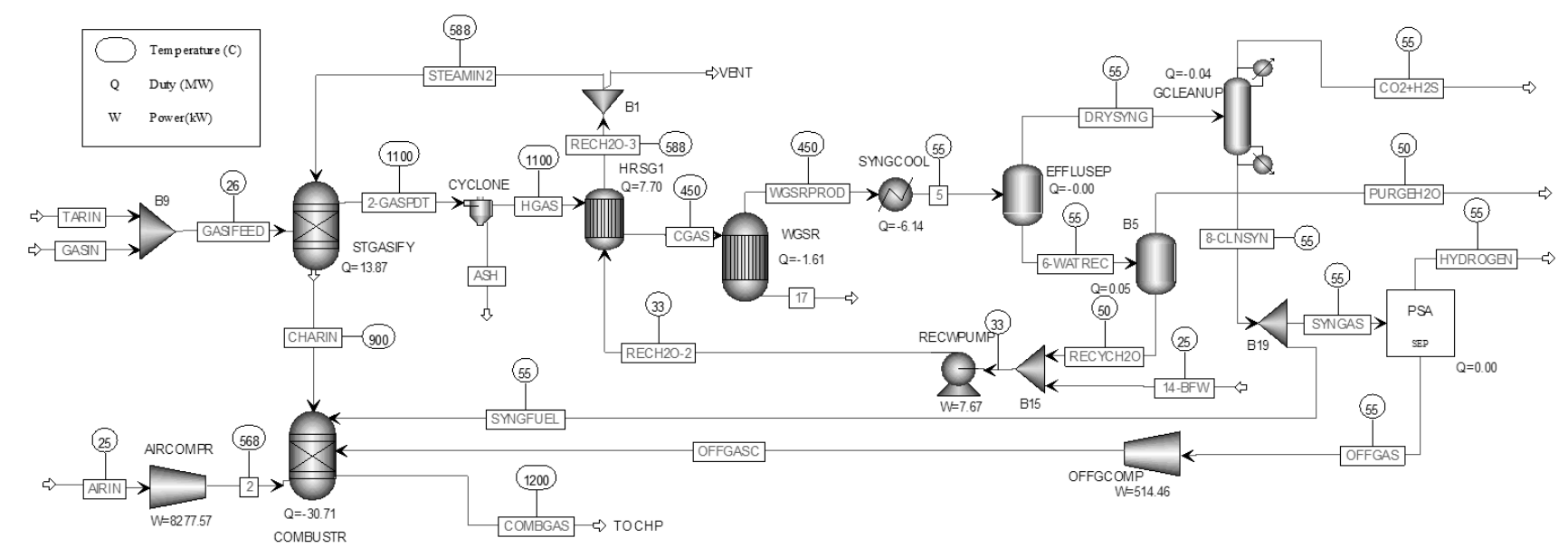

797 Fig. 6 


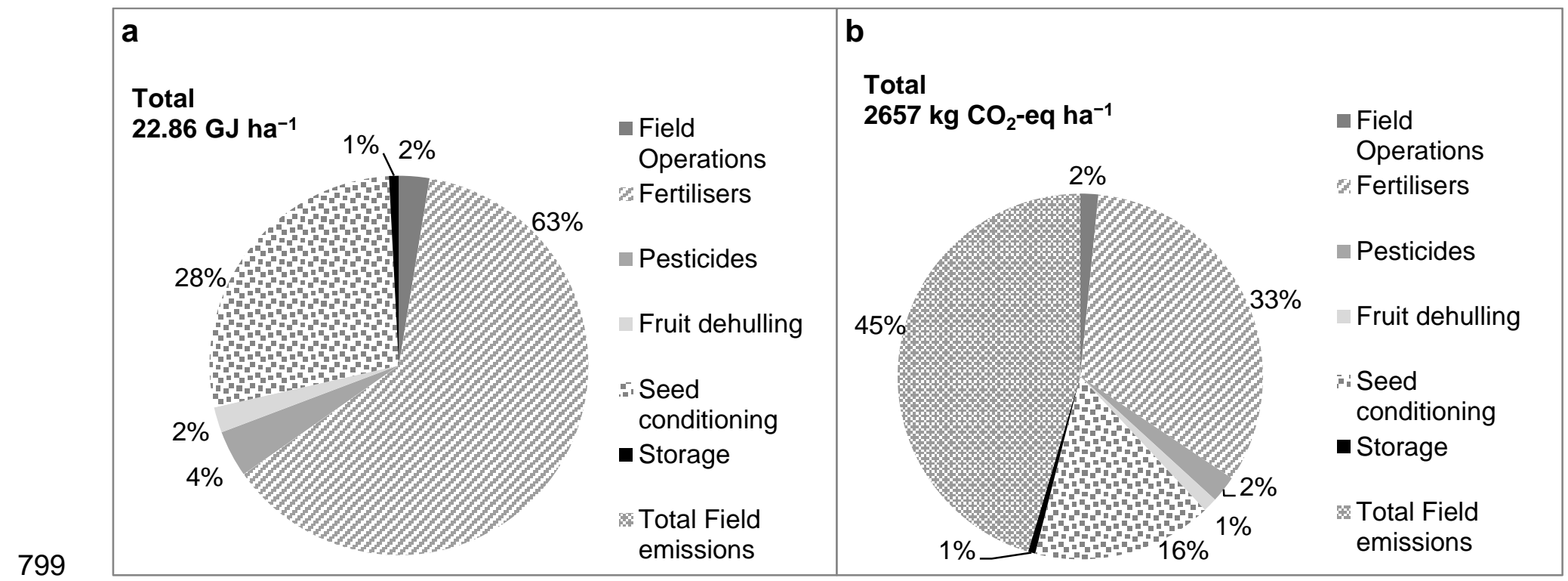

$800 \quad$ Fig. 7

801 


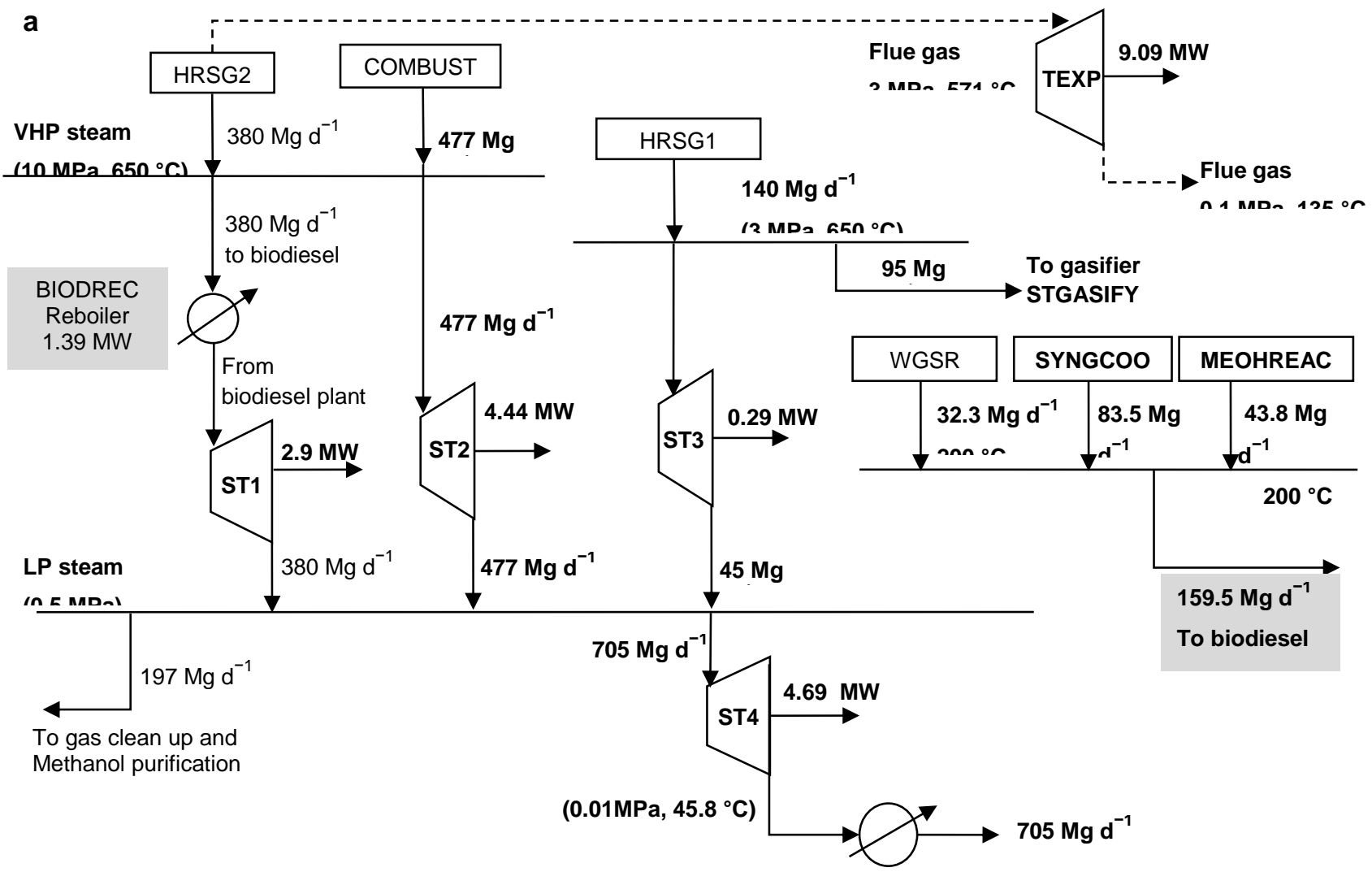




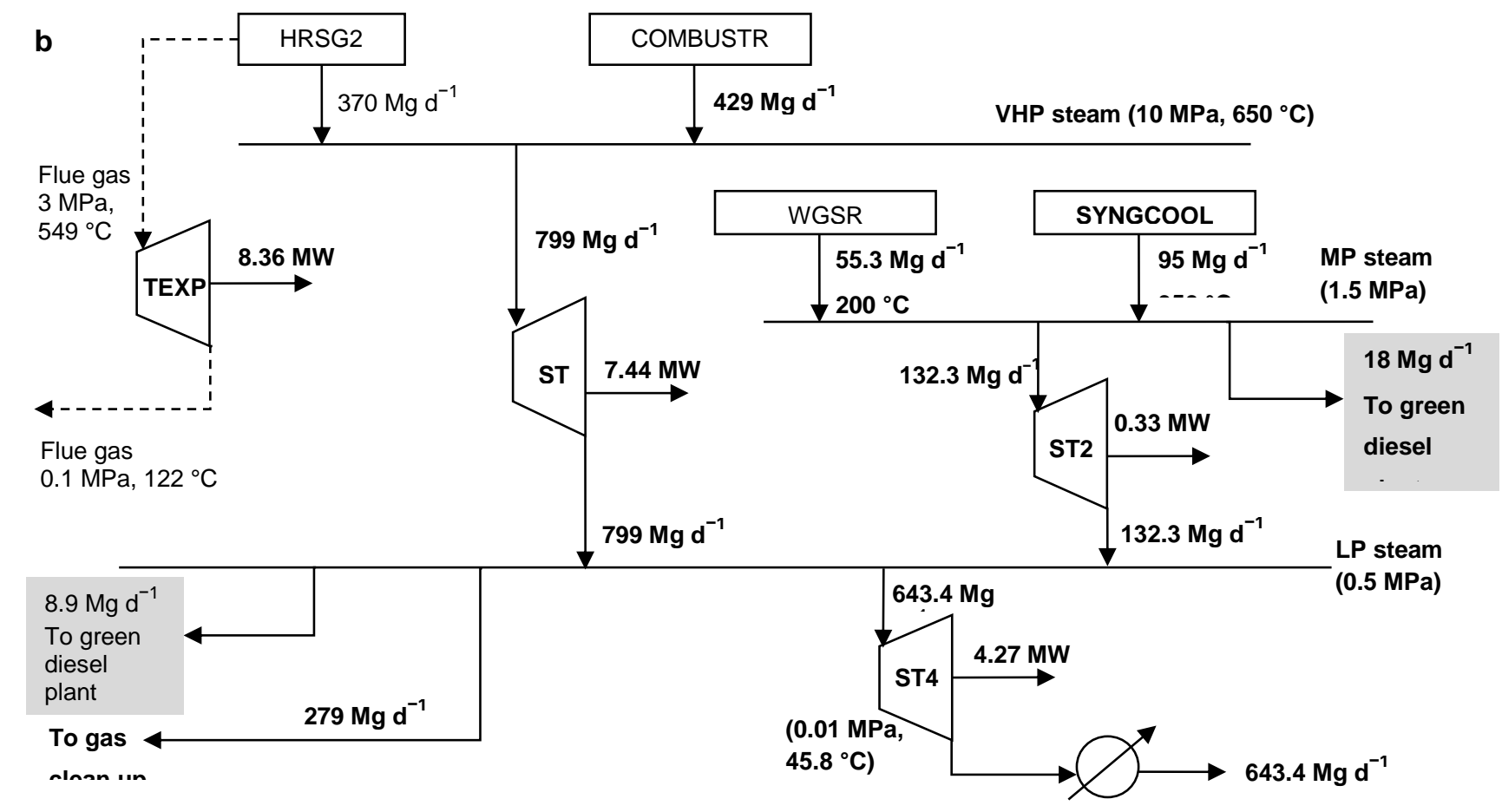

803

$804 \quad$ Fig. 8

805

806

807 

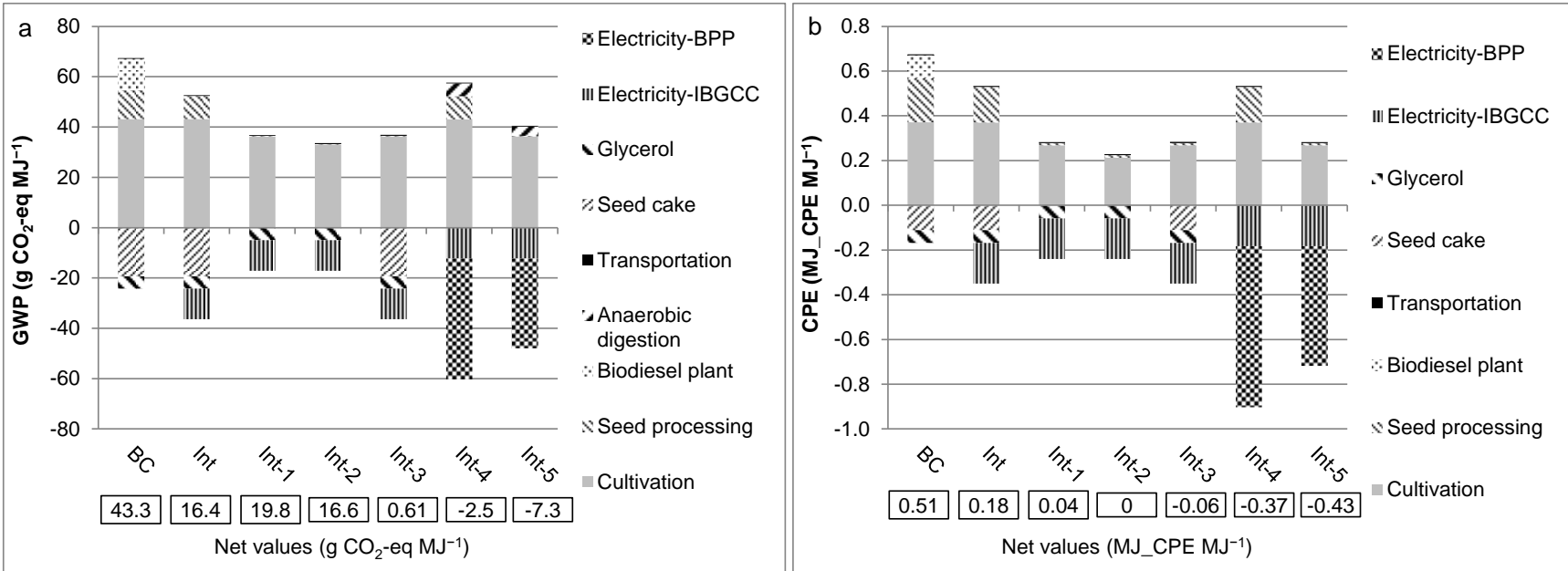

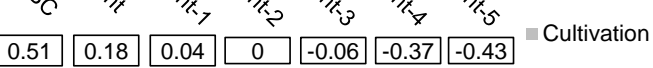
Net values (MJ CPE MJ-1)
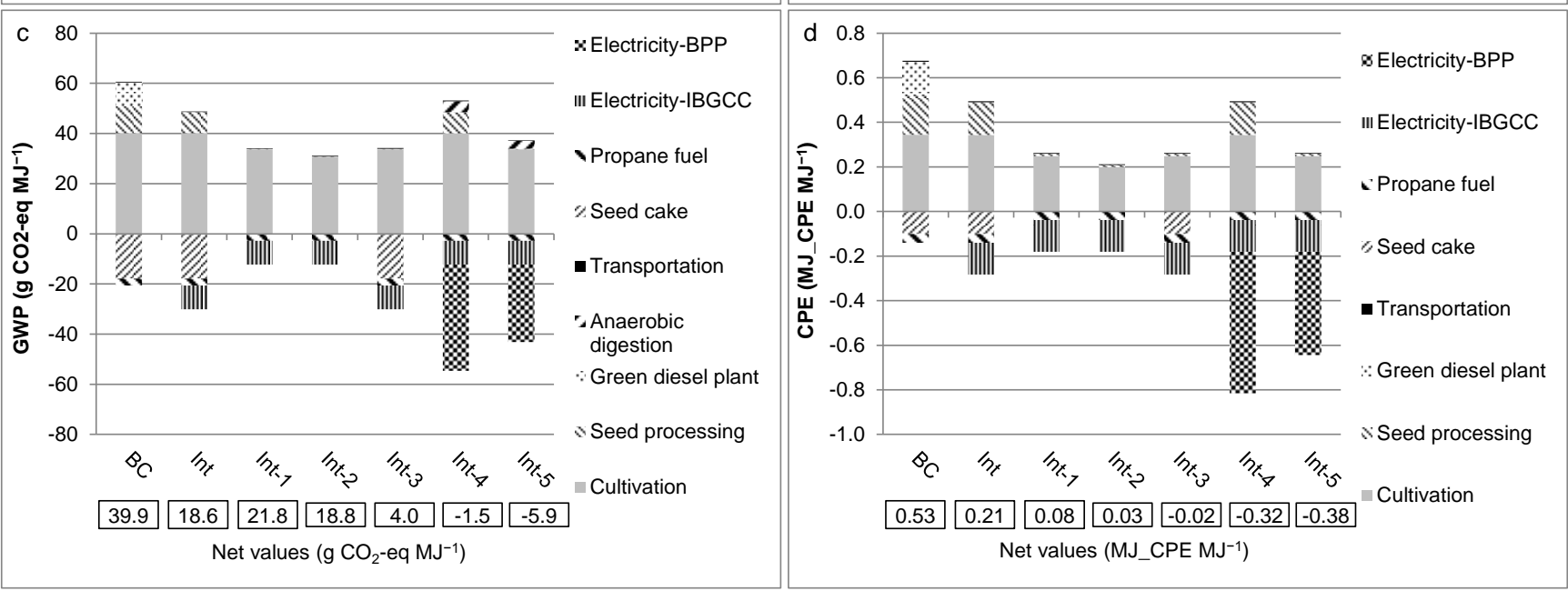

809 Fig. 9 